\title{
Geology and tectonic implications of tourmaline bearing leucogranite of Bastipadu, Kurnool, Andhra Pradesh, India
}

\author{
Kiran Jyoti Mishra, Santanu Bhattacharjee*®o, M S Reddy, \\ M N Praveen, A D Bhimte and N Mahanta \\ Geological Survey of India, Southern Region, Hyderabad 500 068, India. \\ *Corresponding author.e-mail: bhattacharjeesantanu21@gmail.com
}

MS received 17 October 2017; revised 2 January 2018; accepted 19 January 2018; published online 2 August 2018

Tourmaline bearing leucogranite occurs as a pluton with pegmatitic veins intruding the Archaean granodiorite in the Bastipadu area, Kurnool district of Andhra Pradesh. We present field and petrographic relations, mineral chemistry and geochemical data for the leucogranite. It is essentially a two-mica granite, composed of quartz, perthite, microcline, albite, tourmaline and muscovite along with minor biotite and titanite. The euhedral tourmalines are regularly distributed in the rock. The geochemical studies show that the leucogranite is calc-alkaline, peraluminous to metaluminous which formed in a syn-collisional to volcanic arc-related setting. It displays strong ' $\mathrm{S}$ ' type signatures with high $\mathrm{K} / \mathrm{Na}$ ratios, moderately fractionated light rare earth elements, relatively flat heavy rare earth elements with $[\mathrm{Ce} / \mathrm{Yb}]_{\mathrm{N}} \leq 27.8$ and a strong negative Eu anomaly. The geochemical characteristics indicate that the leucogranite melt might have been generated from partial melting of metasediments. Electron probe microanalyser data show the presence of alkali group tourmaline in leucogranite represented by schorl and dravite. Tourmaline compositions plot in the Li-poor granitoids and associated pegmatites and aplites and metapelites/metasammites fields. Partial melting of boron-enriched source rocks is linked with the development of tourmalines in the leucogranite.

Keywords. Bastipadu; tourmaline; borosilicate; schorl; leucogranite.

\section{Introduction}

Leucogranite is one of the occasionally reported and least informative rocks in the granitoids (Moyen et al. 2003). It is associated with tin-tungsten mineralisation as reported from Sewaria-Govindgarh areas of Rajasthan (Pandian and Dutta 2000). The leucogranites from the higher Himalayan belt are better known for their tourmaline content showing variable abundances from pluton to pluton and within a single pluton (Guillot and Le Fort 1995). Jowhar (2010) reported schorl, an Fe-rich variant of tourmaline from the Gangotri granite in the Garhwal Himalaya. Tourmalines are used as semiprecious stones for making ornaments (Pezzotta and Laurs 2011). The study area, around Bastipadu, is spotted with numerous outcrops of leucogranite. It is located 10 $\mathrm{km} \mathrm{SSW} \mathrm{of} \mathrm{Kurnool} \mathrm{in} \mathrm{Andhra} \mathrm{Pradesh} \mathrm{and}$ belongs to the Gadwal schist belt of the Eastern Dharwar Craton (EDC), lying adjacent to the Proterozoic Cuddapah basin (figure 1). Bastipadu is an important sector of the BastipaduChetlamallapuram-Nayakallu corridor as it hosts $\mathrm{Fe}-\mathrm{Cu} \pm \mathrm{Au}-\mathrm{Nb}-\mathrm{Ta}-\mathrm{REEs}$ mineralisation in a geological setting similar to 'Iron Oxide Copper Gold (IOCG) type' (Mishra and Bhattacharjee 2015, 


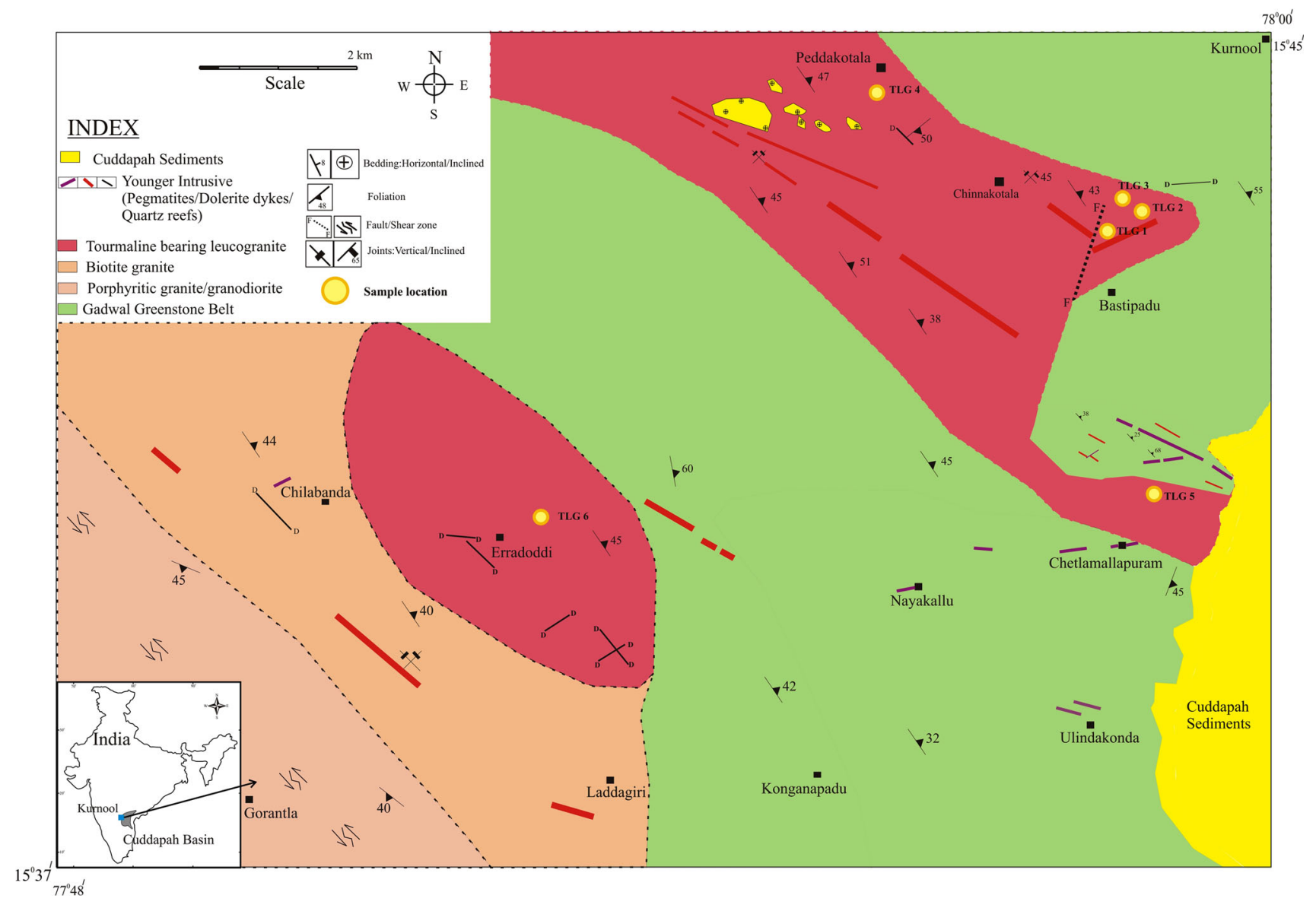

Figure 1. Location and simplified geological map of the study area (after Mishra and Bhattacharjee 2017).

2017; Bhattacharjee et al. 2016; Mishra et al. 2016). Reddy (1994) reported consistent anomalous values of $\mathrm{W}$ (up to $100 \mathrm{ppm}$ ) and B (up to $1086 \mathrm{ppm}$ ) from the geochemical sample in the Bastipadu area. Bhattacharjee et al. (1999) reported the presence of B (up to $1170 \mathrm{ppm}$ ) and W (up to $197 \mathrm{ppm}$ ) north of Chetlamallapuram. Mishra and Bhattacharjee (2015) reported for the first time the presence of columbite and tantalite (Col-Tan), allanite and euxenite bearing mineral phases from the Chetlamallapuram-Bastipadu sector. These were recorded from the pegmatites that intrude the country rocks in the study area. Later on, Mishra et al. (2016) reported rare metal bearing leucogranite-pegmatites from the adjacent areas.

The leucogranite mapped in and around Bastipadu area is marked with intense occurrence of tourmaline which is found ubiquitously from millimetre to centimetre scale and at places also found as quartz-tourmaline rocks within the pegmatitic phases of leucogranite. The presence of tourmaline in the leucogranite is linked with exploration work in hydrothermal mineral systems in general and for tin and tungsten in particular (Charoy 1982; Grew and Anovitz 1996; Henry and Dutrow 1996; London et al. 1996; Slack 1996; Fareeduddin et al. 2010). In many Archaean orogenic and Proterozoic gold deposits, tourmaline forms an important mineral constituent and economically the goldtourmaline veins form some of the world's largest and richest gold deposits (Slack 1996). In India, tourmaline is found in the Kolar gold deposit, Dharwar Craton (Siva Siddaiah and Rajamani 1989), Honnamaradi gold mineralisation in the Chitradurga greenstone belt (Mohakul and Babu 2001), in the outer fringes of the hydrothermal gold mineralised zones, Majjur, Gadag schist belt, Karnataka (Sarma et al. 2004), inner and distal hydrothermal alteration zones of Hira Buddini gold deposit in the Archean Hutti-Maski greenstone belt of the EDC (Krienitz et al. 2008; Hazarika et al. 2015), G.R. Halli gold deposits in the Chitradurga greenstone belt of the Western Dharwar Craton (Gupta et al. 2014). Tourmaline is also helpful in understanding the physical and chemical environments where it forms and retains the chemical signature through geologic time(London and 
Manning 1995; Keller et al. 1999; Dutrow and Henry 2011). The main role played behind the scene is 'boron', an indispensable element for the formation of tourmaline (Dutrow and Henry 2011). The availability of boron in the source is linked to the tourmaline development in the granitic rock such as the higher Himalayan leucogranites (Dutrow and Henry 2011).

Tourmaline-rich leucogranite is exposed to a considerable portion in and around the study area. No attempt has been made so far for the detailed geological and geochemical study of this litho unit and also to classify the associated tourmaline. In the present work, attempt has been made to document mineralogy, chemical composition and classification of tourmaline associated with leucogranite. Detailed petrographic studies, mineral chemistry and geochemical characterisation of leucogranite have also been carried out with an attempt to deduce the tectonic setting.

\section{Geological setting}

The study area forms a part of EDC which is a typical Archaean-granite-greenstone terrain with sediments of Meso- to Neoproterozoic intracratonic Cuddapah Basin unconformably resting over it. It exposes rocks of Gadwal greenstone belt of Archaean age and younger granitoids of Archaean to Paleoproterozoic age along with Cuddapah sediments of Mesoproterozoic age (table 1 and figure 1). The Gadwal litho are represented by quartz \pm chlorite \pm sericite \pm actinolite schist, agglomerate, metaandesite and dacite to rhyo-dacite, metarhyolite and banded iron formation (Srinivasan and Nagaraja Rao 1992). The granitoids in the study area belong to tonalite-granodioritemonzogranite (TGM) suite, represented by porphyritic granite/granodiorite and the younger monzogranite-syenogranite (MS) suite, represented by biotite and tourmaline bearing leucogranite.

Table 1. Stratigraphy worked out for the study area (after Mishra et al. 2016).

Cuddapah sediments

Unconformity

Younger intrusive (pegmatites/dolerite dykes/quartz reefs)

Tourmaline bearing leucogranite (MS suite)

Biotite granite (MS suite)

Porphyritic granite/granodiorite (TGM suite)

Gadwal greenstone belt
The granitoids intrude the schist belt components. These are in turn intruded by pegmatites (both K-feldspar rich and albite rich), gabbro/dolerite dyke and quartz reefs along the large-scale faults. The large-scale potash metasomatism along the fault planes resulted in the formation of K-feldspar bearing pegmatites. These pegmatites host the $\mathrm{Fe}-\mathrm{Cu}$ minerals in a geological setting similar to the 'IOCG' type (Mishra and Bhattacharjee 2015, 2017; Bhattacharjee et al. 2016; Mishra et al. 2016). The albite-rich leucopegmatite is associated with $\mathrm{Nb}-\mathrm{Ta}$ mineralisation in the area (Mishra et al. 2016). The older units are unconformably overlain by the Cuddapah sediments including the Gulcheru conglomerate and quartzite of the Cuddapah Supergroup.

\section{Tourmaline bearing leucogranite}

\subsection{Field relation and host rock description}

The leucogranite intrudes into the Gadwal schist belt and older granitoids. It is found over large areas in Bastipadu, Chetlamallapuram, Chinnakotala, Ulindakonda, Erradoddi, Laddagiri, etc. (figure 1) and occurs as small plugs within the older litho units. The exposures are cropped out in and around Bastipadu (figure 2a) where it mostly occurs as small hills/mounds, isolated patches and bouldery outcrops. The leucogranite is medium to coarse grained, light or milky white coloured. The colour changes locally to light grey and pink due to large-scale tourmalinisation and potash metasomatism (Mishra et al. 2016; Mishra and Bhattacharjee 2017). The constituent mineralogy includes quartz, albite, microcline, muscovite and tourmaline on millimetre to centimetre scale. The rock becomes locally very coarse grained showing the pegmatitic texture with the size of individual grain exceeding $1 \mathrm{~cm}$ (figure $2 \mathrm{~b}$ ). The pegmatite occurs as a sheet within the main leucogranite, where the size of tourmaline crystal reaches up to $11 \mathrm{~cm}$ in length (figure 2c). Tourmalines within leucogranite host occur as fine-to-coarse disseminations, clusters/aggregations (figure 2a) and vein fillings/crude laminations. The crystals are prismatic in nature with their characteristic striations. At places, these are seen radiating from a common centre (figure 2c). Some fine-grained leucogranitic sheets with numerous fine crystals of tourmaline occur as linear bands (flow bands) within the main unit (figure 2d). This probably indicates the quick chilling of some 

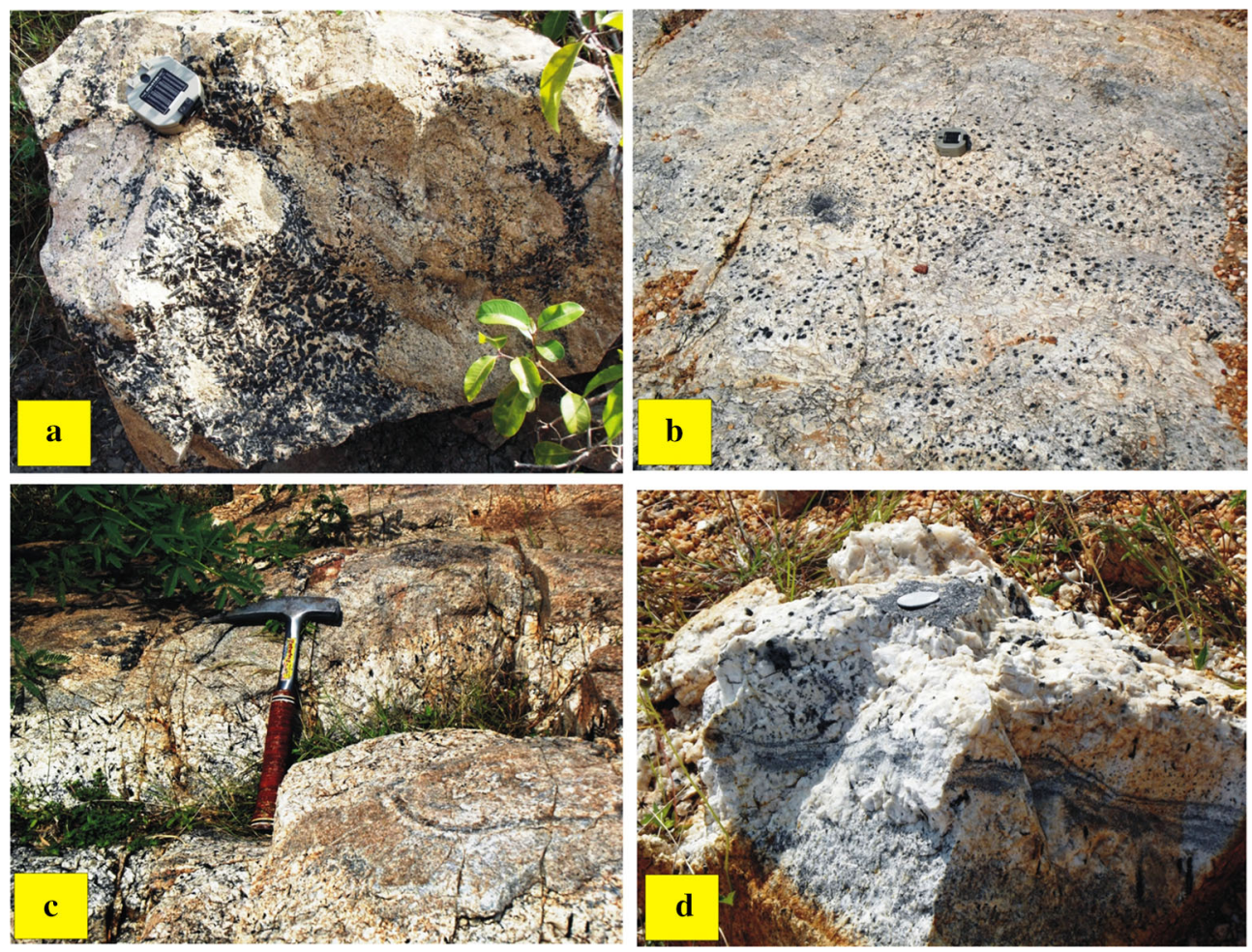

Figure 2. (a) Field photograph of medium- to coarse-grained leucogranite containing mm to cm scale black coloured tourmaline. (b) Field photograph of very coarse-grained leucogranite and at places displays a pegmatitic texture with the presence of disseminated tourmaline in the silicic groundmass. (c) Field photograph of horizontal sheet-like quartz-albite rich pegmatite emplaced within the leucogranite unit and contains $\mathrm{cm}$ scale tourmaline. (d) Field photograph showing the crude alignment of fine-grained tourmaline in leucogranite.

pulses of the granite (Cobbing 2008). Locally along some fault planes the leucogranite is seen to become pink coloured with excess enrichment of K-felspar. One such is seen north of Bastipadu within leucogranite where a NW-SE trending quartz reef is emplaced along a fault accompanied by K-metasomatism. Later faults offset it and this resulted in the change of the Hundri River course suddenly from west to south (Mishra and Bhattacharjee 2015).

\subsection{Petrography}

Under a microscope, leucogranite (figure $3 \mathrm{a}-\mathrm{c}$ ) comprises quartz (30-40\%), albite (20-25\%), perthite and K-feldspar (15-20\%), muscovite (2$5 \%)$ and tourmaline (5-10\%). The rock is fine to coarse grained and shows hypidiomorphic texture. Both orthoclase and microcline are observed. K-feldspars alter to sericite and appear cloudy (figure $3 \mathrm{a}$ and $\mathrm{c}$ ). Graphic intergrowth of quartz in $\mathrm{K}$-feldspar host is also recorded. Plagioclase occurs as clouded subhedral to anhedral crystals. Bent twin lamellae in some plagioclase are also observed which may be due to the local scale deformation.
Clouding of plagioclase crystals is attributed to the development of white mica/sericite. Both muscovite and biotite occur with the dominance of the former over the latter. Peripheral granulations due to the deformation along the margins of the individual quartz crystals are also seen (figure 3f). Tourmaline in leucogranite occurs as euhedral slender needles (figure $3 \mathrm{~d}$ and e) and is identified as schorl and dravite species (figure 4a and b). These are identified by their dark blue, green and light to dark brown colour and pleochroism in shades of light to dark brown under crossed polarised light (XPL) (figure 3a-f). Poikilitic inclusions of quartz within tourmaline are also observed (figure 3ac). Some crystals of tourmaline occur as anhedral inclusions within K-feldspars (figure 3a). Twinning and zoning are also observed in this schorl species of tourmaline (figure 3c). Thick veins of tourmaline crystallite and microlites with later crosscutting leucoveins are also recorded. The tourmaline veins display honeycomb structures indicating tourmalinisation along microfractures (figure 3d). Zoning in tourmaline is clearly observed (figures 3a and $4 \mathrm{a}$ ). The inclusion of hematite is also observed in tourmaline (figure $4 \mathrm{~b}$ and $\mathrm{c}$ ). 

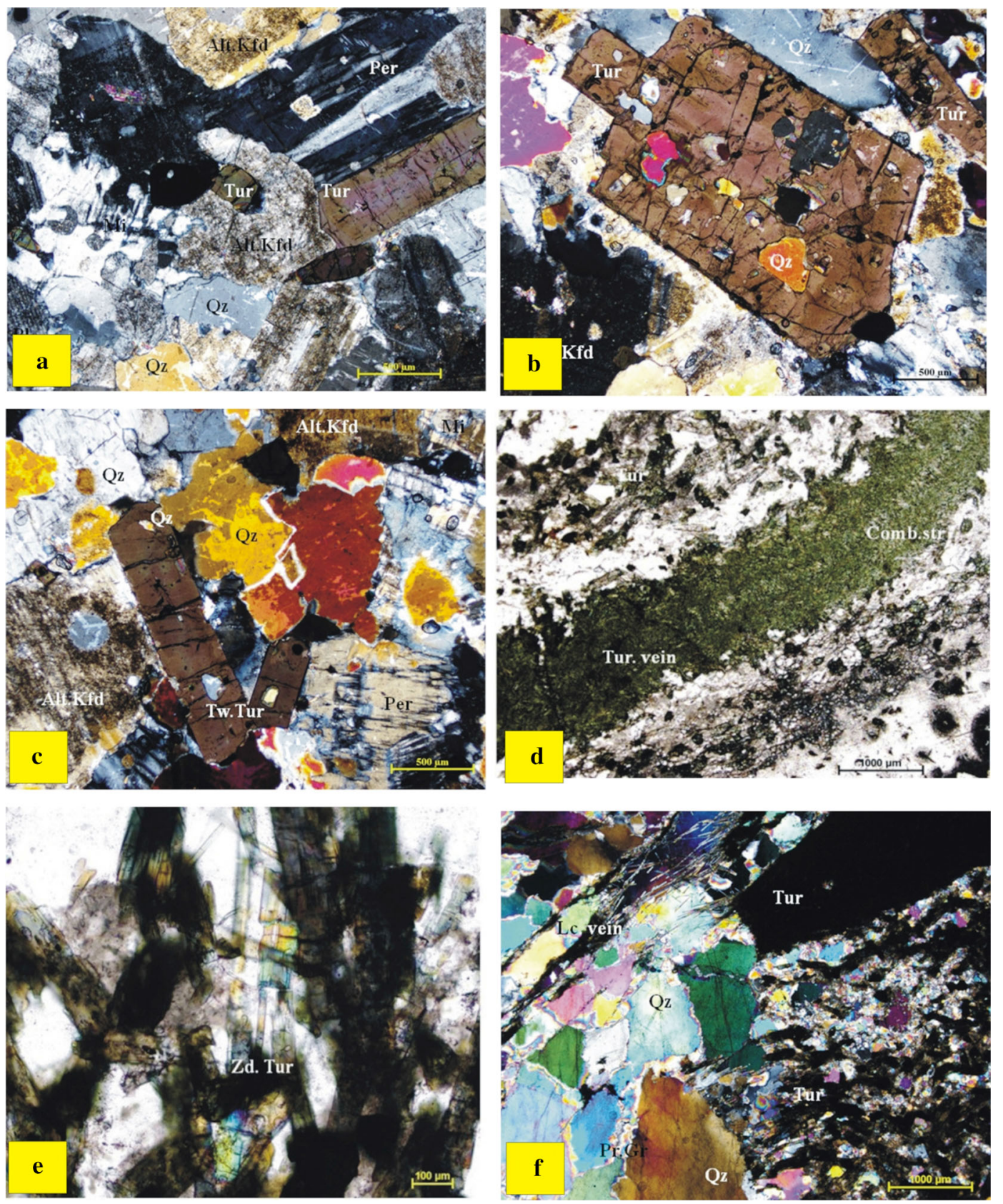

Figure 3. (a) Photomicrograph showing the presence of quartz (Qz), altered K-feldspar (Alt.Kfd), plagioclase (Pl), tourmaline (Tur), microcline (Mi) and perthite (Per) in leucogranite (TL; XPL). (b) Photomicrograph showing the presence of quartz, altered K-feldspar and tourmaline in the leucogranite. Tourmaline contains poikilitic inclusions of quartz (TL; XPL). (c) Photomicrograph showing the presence of quartz, altered K-feldspar, microcline, perthite and twinned tourmaline in leucogranite. K-feldspar is replaced by microcline (TL; XPL). (d) Photomicrograph showing the presence of tourmaline veins displaying honeycomb structures (TL; XPL). (e) Photomicrograph showing clusters of zoned tourmaline (Zd.Tur) in the leucogranite (TL; XPL). (f) Photomicrograph of leucogranite showing crosscutting thick tourmaline and later leucoveins (Lc. vein) (TL; XPL).

\section{Analytical methods}

Quantitative analyses of mineral phases for major elements were carried out by wavelength dispersive spectrometry using a CAMECA SX100 electron probe microanalyser (EPMA) at the Petrology
Division, Geological Survey of India, Southern Region, Hyderabad. The analytical conditions were of an accelerating voltage of $15 \mathrm{kV}$ and $20 \mathrm{nA}$ probe current with $1 \mu \mathrm{m}$ beam diameter. Standards used were as follows: $\mathrm{Na}$ on albite, $\mathrm{Mg}$ on periclase, $\mathrm{Si}$ and $\mathrm{Ca}$ on wollastonite, $\mathrm{Al}$ on 

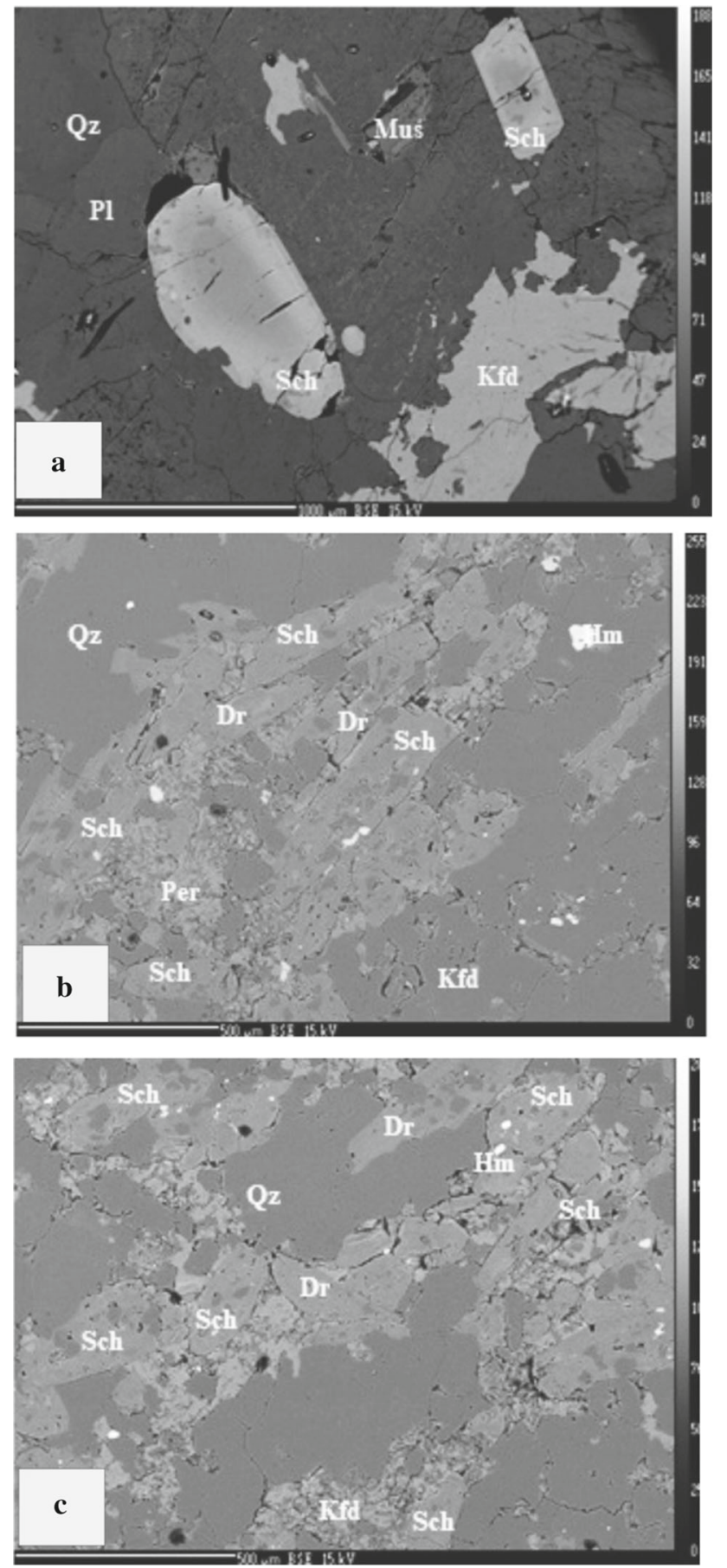

Figure 4. (a) Back scattered electron (BSE) image of schorl (Sch) variant of tourmaline showing concentric zoning. (b) BSE images showing the presence of schorl (Sch) and dravite (Dr) in leucogranite. Inclusions of hematite are seen within schorl. (c) BSE images showing the presence of schorl (Sch) and dravite (Dr) in leucogranite. Inclusions of hematite are seen within schorl.

corundum, $\mathrm{K}$ on orthoclase, $\mathrm{Ti}$ on ilmenite, $\mathrm{Cr}$ on chromium, $\mathrm{Mn}$ on rhodonite, Fe on hematite and $\mathrm{P}$ on apatite. ZAF matrix corrections were performed after Philibert (1963). The emission line used was K $\alpha$. A PET crystal was used for Ca and $\mathrm{Ti}$; TAP crystal for Na, Mg, Si and Al; LPET crystal for $\mathrm{K}$ and $\mathrm{Cr}$; and LIF crystal for Mn and Fe. The generated mineral chemistry data of feldspars of leucogranite were processed using MINPET software. The microprobe data of tourmaline were processed for cations and mineral formula calculation using the Excel spreadsheet developed by Julie Seley and Jian Xiang (Selway 2015) and confirmed manually. Cations were calculated based on 31 oxygen atoms as it would give an accurate and useful formula [(assuming $\mathrm{OH}+\mathrm{F}=4$ atoms per formula unit (apfu)] and accommodate $\mathrm{F}$ compared to schemes that ignore $\mathrm{F}$ or $\mathrm{B}$. Atomic proportion was calculated by assuming boron's stoichiometric value of 3 apfu and $\mathrm{OH}+\mathrm{F}=4$ apfu. Lithium was estimated by subtracting the cations sum of $\mathrm{T}, \mathrm{Z}$ and $\mathrm{Y}$ sites from 15 , i.e., $\mathrm{Li}=15-$ total $(\mathrm{T}+\mathrm{Z}+\mathrm{Y})$. The proportion of $\mathrm{B}_{2} \mathrm{O}_{3}, \mathrm{H}_{2} \mathrm{O}$ and $\mathrm{Li}_{2} \mathrm{O}$ was calculated by stoichiometry. $\mathrm{B}_{2} \mathrm{O}_{3}$ is required to produce three boron cations and $\mathrm{Li}_{2} \mathrm{O}$ is required to fulfil the cation deficiencies in the $\mathrm{Y}$ site. The $\mathrm{Fe}_{\text {total }}$ was assumed to be all $\mathrm{Fe}^{2+}$.

Geochemical analyses were carried out at the Chemical Division, Geological Survey of India, Southern Region, Hyderabad. Fresh samples were collected from leucogranitic outcrops. Utmost care was taken during the collection of samples and altered portions were strictly avoided. Major, minor and trace elements of the rock were analysed using a M/S Panalytical, MAGIX, $2.4 \mathrm{~kW}$ sequential $\mathrm{X}$-ray fluorescence (XRF) spectrometer using the pressed pellet method. The pellet was made by spreading $5.0 \pm 0.01 \mathrm{~g}$ of powdered sample in the aluminium cup having $40 \mathrm{~mm}$ diameter over the boric acid powder and pressed into a pellet under a pressure of 20 tons: with the help of a hydraulic press pellet machine to get a uniform pressed pellet. Care was taken to avoid the formation of cracks on the surface of the pellet. Total iron is determined as $\mathrm{Fe}_{2} \mathrm{O}_{3}$. The detection limit is $0.1 \%$ for major and minor elements and $1.00 \mathrm{ppm}$ for trace elements. The precision of the instrument is $\pm 10 \%$. Rare earth elements were analysed using a Perkin Elmer Sciex ELAN 6100 inductively coupled plasma mass spectrometer (ICP-MS). Fusion method was used for the analyses. The method has quantification limits from 0.1 to $1 \mathrm{ppm}$ and precision of the instrument is $\pm 10 \%$. All the datasets were processed using 'IGPET and GCD-Kit' software programmes. 


\section{Results and discussion}

\subsection{Mineral chemistry}

\subsubsection{Feldspar}

The microprobe data (tables 2 and 3) of feldspars from the leucogranite show that the albite is composed of $\mathrm{Ab}_{95}$ and $\mathrm{An}_{5}$ and orthoclase is composed of $\mathrm{Or}_{97.6}$ and $\mathrm{Ab}_{2.5}$. These two occupy the orthoclase and albite vertex in the Ab-Or-An ternary diagram (figure $5 \mathrm{a}$ and $\mathrm{b}$ ).

\subsubsection{Tourmaline}

Hawthorne and Henry (1999) and Dutrow and Henry (2011) have defined the basic formula of tourmaline as $\mathrm{XY}_{3} \mathrm{Z}_{6}\left(\mathrm{~T}_{6} \mathrm{O}_{18}\right)\left(\mathrm{BO}_{3}\right) \mathrm{V}_{3} \mathrm{~W}$, where $\mathrm{X}=\mathrm{Na}, \mathrm{Ca}, \mathrm{K}$, vacancy; $\mathrm{Y}=\mathrm{Fe}^{2+}, \mathrm{Mg}, \mathrm{Mn}^{2+}$, $\mathrm{Li}, \mathrm{Al}, \mathrm{Cr}^{3+}, \mathrm{V}^{3+}, \mathrm{Fe}^{3+},\left(\mathrm{Ti}^{4+}\right) ; \mathrm{Z}=\mathrm{Mg}, \mathrm{Al}$, $\mathrm{Fe}^{3+}, \mathrm{V}^{3+}, \mathrm{Cr}^{3+} ; \mathrm{T}=\mathrm{Si}, \mathrm{Al},(\mathrm{B}) ; \mathrm{V}=\mathrm{OH}, \mathrm{O}$; $\mathrm{W}=\mathrm{OH}, \mathrm{F}, \mathrm{O}$. Generally, chemical substitution of tourmaline mainly occurs in the $\mathrm{X}, \mathrm{Y}$ and $\mathrm{Z}$ sites (Foit and Rosenberg 1977; Rosenberg and Foit 1979; Henry and Guidotti 1985; Grice and Robinson 1989). The cations calculation in the respective sites of tourmalines is presented in table 4 and discussed as follows. In the $\mathrm{T}$ site, $\mathrm{Al}$ varies from 0.0 to 0.234 . In $\mathrm{Y}$ sites, $\mathrm{Al}$ varies from 0.0 to $0.591, \mathrm{Mg}$ varies from 0.0 to $1.506, \mathrm{Fe}^{2+}$ varies from 0.522 to $3.081, \mathrm{Mn}$ varies from 0.0 to 0.239 and $\mathrm{Ti}$ varies from 0.004 to 0.136 . The $\mathrm{Fe} / \mathrm{Fe}+$ $\mathrm{Mg}$ ratios vary from 0.289 to 1.0 in the $\mathrm{Y}$ site. In the $\mathrm{X}$ site, $\mathrm{Ca}$ varies from 0.008 to $0.242, \mathrm{Na}$ varies from 0.495 to 0.975 and $\mathrm{K}$ varies from 0.002 to 0.061 . The $\mathrm{Ca}+\mathrm{Na}$ varies from 0.501 to 0.984 and $\mathrm{Ca} / \mathrm{Ca}+\mathrm{Na}$ ratio varies from 0.009 to 0.289 . As per the dominant occupancy of the X-site, these fall on the alkali field of the primary tourmaline group (figure 5c; Henry et al. 2011) where $\left(\mathrm{Na}^{1+}+\mathrm{K}^{1+}\right) \geq \mathrm{Ca}^{2+}$ and $\left(\mathrm{Na}^{1+}+\mathrm{K}^{1+}\right) \geq \mathrm{X}-$ vacant. $\mathrm{Na}^{1+}+\mathrm{K}^{1+}$ value ranges from 0.499 to $0.982, \mathrm{Ca}^{2+}$ value ranges from 0.008 to 0.242 and $\mathrm{X}$-vacant value ranges from 0.009 to 0.487 . In all the cases, these are in agreement with the alkali group tourmalines (Henry et al. 2011). Based on the plot of $\mathrm{Ca} /(\mathrm{Na}+\mathrm{Ca})$ in the $\mathrm{X}$ site and $\mathrm{Fe} /$ $(\mathrm{Fe}+\mathrm{Mg})$ in the $\mathrm{Y}$ site, these tourmalines fall in the schorl and dravite fields (figure $5 \mathrm{~d}$; Tindle et al. 2002). Adequate presence of $\mathrm{Fe}$ and/or $\mathrm{Mg}$ and $\mathrm{Al}$ in the system is responsible for the formation of schorl and dravite (Manning 1981; Morgan

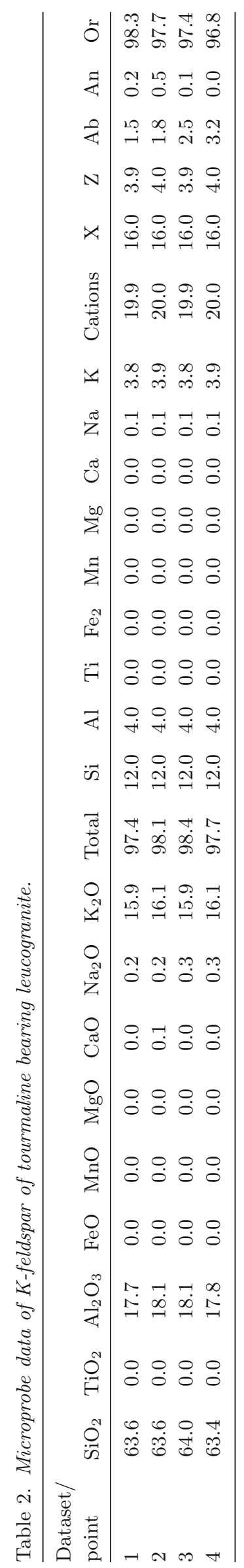




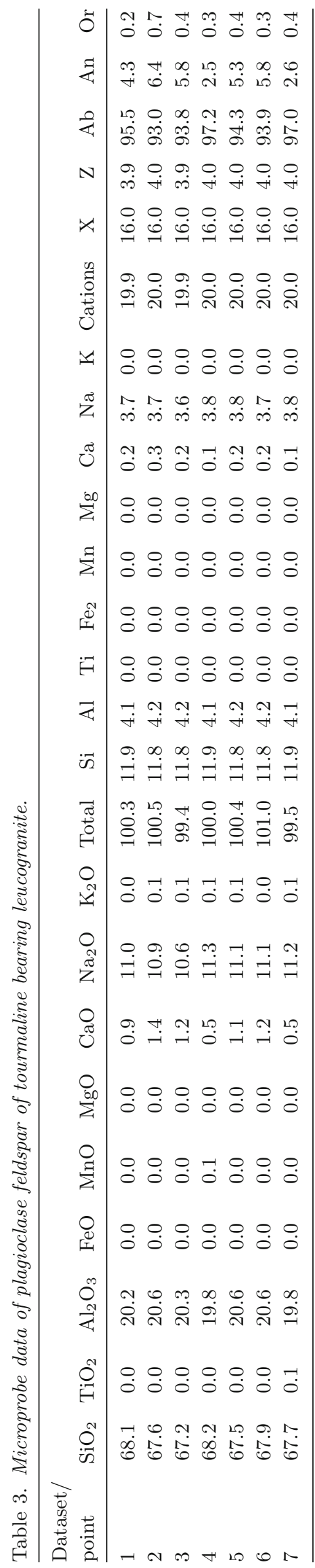

and Landon 1987; London and Manning 1995). Higher concentration of $\mathrm{Fe}^{2+}, \mathrm{Mn}^{2+}$ and/or $\mathrm{Ti}^{4+}$ imparts a black colouration to these species (Zang and da Fonseca-Zang 2002). The majority of tourmaline composition from the study area (figure 5e) plot in the Li-poor granitoids and associated pegmatites and aplites field and few fall in the fields of metapelites and metapsammites in the AFM plot of Henry and Guidotti (1985). Al in the $\mathrm{T}$ site varies up to 0.234 . In the $\mathrm{Y}$ site, $\mathrm{Al}$ varies up to $0.591, \mathrm{Mg}$ varies up to $1.506, \mathrm{Fe}^{2+}$ varies from 0.522 to $3.081, \mathrm{Mn}$ varies up to 0.239 and $\mathrm{Ti}$ varies from 0.004 to $0.136 . \mathrm{Fe} / \mathrm{Fe}+\mathrm{Mg}$ ratios vary from 0.289 to 1.0 in the $\mathrm{Y}$ site. In the $\mathrm{X}$ site, $\mathrm{Ca}$ varies from 0.008 to $0.242, \mathrm{Na}$ varies from 0.495 to 0.975 and $\mathrm{K}$ varies from 0.002 to 0.061 . $\mathrm{Ca}+\mathrm{Na}$ varies from 0.501 to 0.984 . $\mathrm{Ca} / \mathrm{Ca}+\mathrm{Na}$ ratio varies from 0.009 to 0.289 .

\subsection{Geochemistry}

The geochemical data (table 5) show high $\mathrm{SiO}_{2}$ and $\mathrm{Al}_{2} \mathrm{O}_{3}$ content from 72.02 to $76.09 \mathrm{wt} \%$ and 12.74 to $15.1 \mathrm{wt} \%$, respectively. $\mathrm{Fe}_{2} \mathrm{O}_{3}$ and $\mathrm{MgO}$ content varies from 0.21 to $1.58 \mathrm{wt} \%$ and 0.07 to 0.69 wt\%, respectively. $\mathrm{TiO}_{2}, \mathrm{MnO}$ and $\mathrm{P}_{2} \mathrm{O}_{5}$ content also varies and recorded up to $0.32,0.04$ and $0.23 \mathrm{wt} \%$, respectively. The $\mathrm{CaO}$ content varies between 0.3 and $1.57 \mathrm{wt} \%$. The $\mathrm{Na}_{2} \mathrm{O}$ content varies from 3.1 to $4.3 \mathrm{wt} \%$ and $\mathrm{K}_{2} \mathrm{O}$ content varies from 3.5 to 7.1 and the $\mathrm{K}_{2} \mathrm{O}$ vs. $\mathrm{Na}_{2} \mathrm{O}$ ratio varies from 0.859 to $2.034 \mathrm{wt} \%$. The trace elements show consistently low values except for the $\mathrm{Cr}$ content which varies from 34 to $129 \mathrm{ppm}$. $\mathrm{Zn}$ and $\mathrm{Cu}$ contents are also very low. The Ga content varies from 12 to $30 \mathrm{ppm}$. Y shows values up to $57 \mathrm{ppm}$. The large ion lithophile elements (LILE) such as $\mathrm{Rb}, \mathrm{Sr}$ and $\mathrm{Ba}$ of the rock are high and vary from 145 to 943,18 to 153 and 25 to $346 \mathrm{ppm}$, respectively. The high field strength elements (HFSE) content is also high, consistent with the incompatible nature of these elements, and recorded the values of $\mathrm{Zr}$, $\mathrm{Hf}, \mathrm{Nb}, \mathrm{Ta}$, Th and $\mathrm{U}$ from 2.5 to $317,1.1$ to 7.4, 7 to 196,1 to 123,11 to 32 and 2.5 to 34 ppm, respectively. The light rare earth elements (LREE: La to Sm) and heavy rare earth elements (HREE: Eu to Lu) content of leucogranite varies from 27 to 669 and 8 to $36 \mathrm{ppm}$, respectively, along with high LREE/HREE ratio of 3-13 (table 5). 

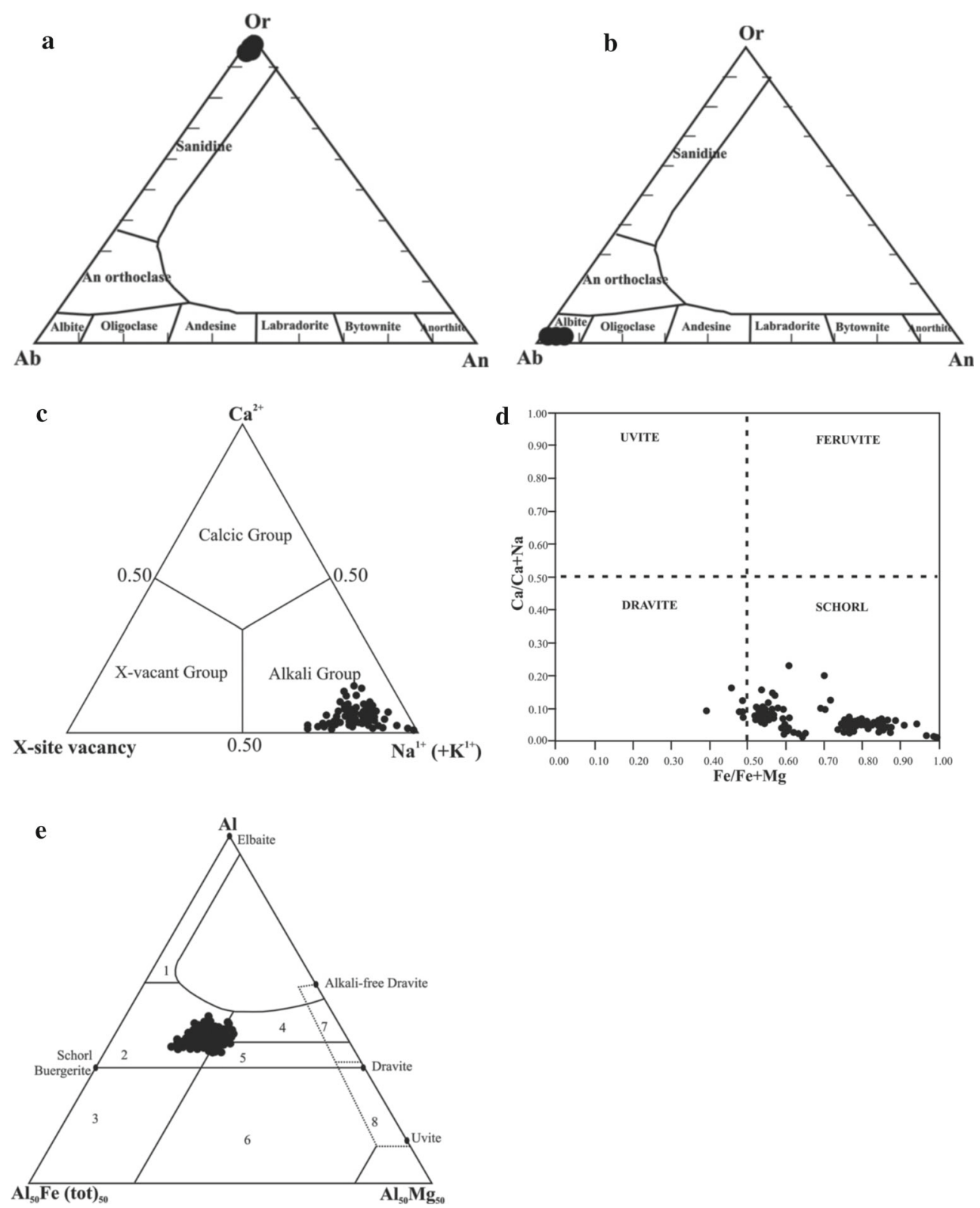

Figure 5. (a) Composition of potash feldspar from leucogranite. (b) Composition of plagioclase feldspar from leucogranite. (c) Ternary system for the primary tourmaline groups based on the dominant occupancy of the X-site (after Henry et al. 2011). (d) Classification of tourmaline on the basis of $\mathrm{Ca} /(\mathrm{Na}+\mathrm{Ca})$ in the $\mathrm{X}$ site and $\mathrm{Fe} /(\mathrm{Fe}+\mathrm{Mg})$ in the $\mathrm{Y}$ site shows that these falls on the schorl and dravite fields (Tindle et al. 2002). The majority of the tourmaline falls on the schorl field due to the higher Fe content. (e) Al-Fe-Mg ternary diagram for tourmaline from the Bastipadu area. Numbered fields after Henry and Guidotti (1985): (1) Li-rich granitoids and associated pegmatites and aplites; (2) Li-poor granitoids and associated pegmatites and aplites; (3) $\mathrm{Fe}^{3+}$-rich quartz-tourmaline rocks and hydrothermally altered granites; (4) metapelites and metapsammites coexisting with an Al-saturating phase; (5) metapelites and metapsammites not coexisting with an Alsaturating phase; (6) $\mathrm{Fe}^{3+}$-rich quartz-tourmaline rocks, calc-silicate rocks and metapelites; (7) low-Ca metaultramafics and Cr, V-rich metasediments; and (8) metacarbonates and metapyroxenites. From the diagram it is known that tourmaline compositions from the leucogranites of the Bastipadu area fall in the field 2 of Li-poor granitoids and their associated pegmatites and aplites.

The Quartz Alkali Feldspar Plagioclase (QAP) plot of Streckeisen (1976) shows that the leucogranite falls in the syenogranite and monzogranite fields (figure 6a). They exhibit a calcalkaline trend (figure 6b) as per Irvine and Baragar (1971). As per the $\mathrm{Al} /(\mathrm{Na}+\mathrm{K})$ vs. $\mathrm{Al} /(\mathrm{Ca}+\mathrm{Na}+\mathrm{K})$ plot, it falls mostly in the peraluminous field and few fall at the junction of meta- to peraluminous fields (figure 6c; Shand and Spurr 1943). The A/NK vs. A/CNK value varies from 1.1 to 1.33 and 1.9 


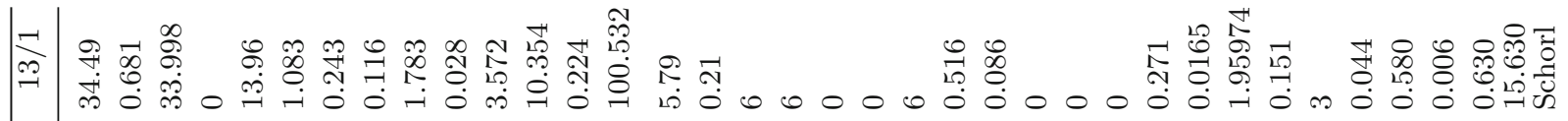

군 न मी

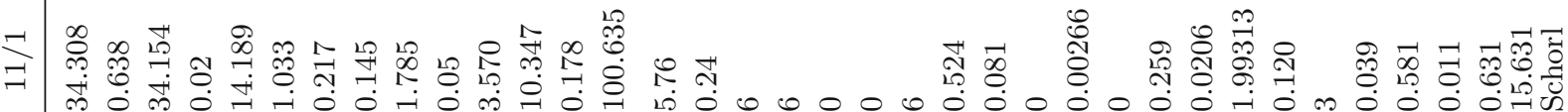

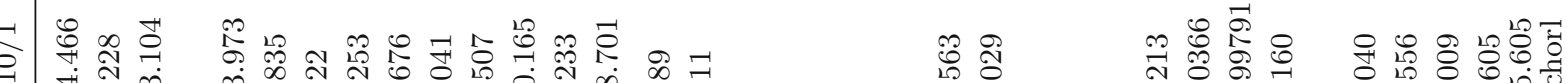

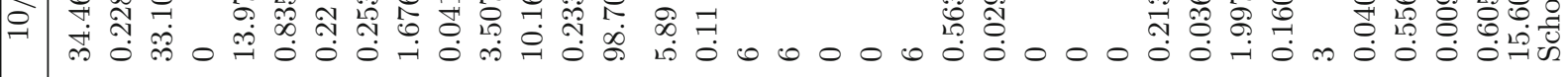

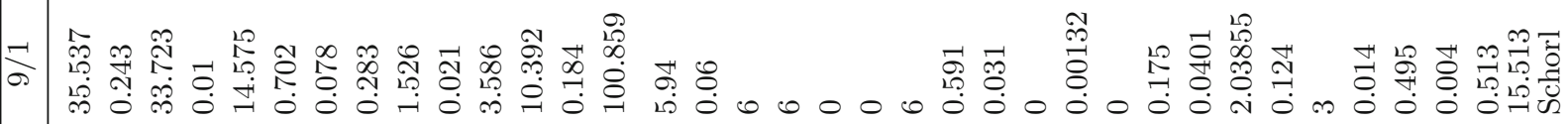

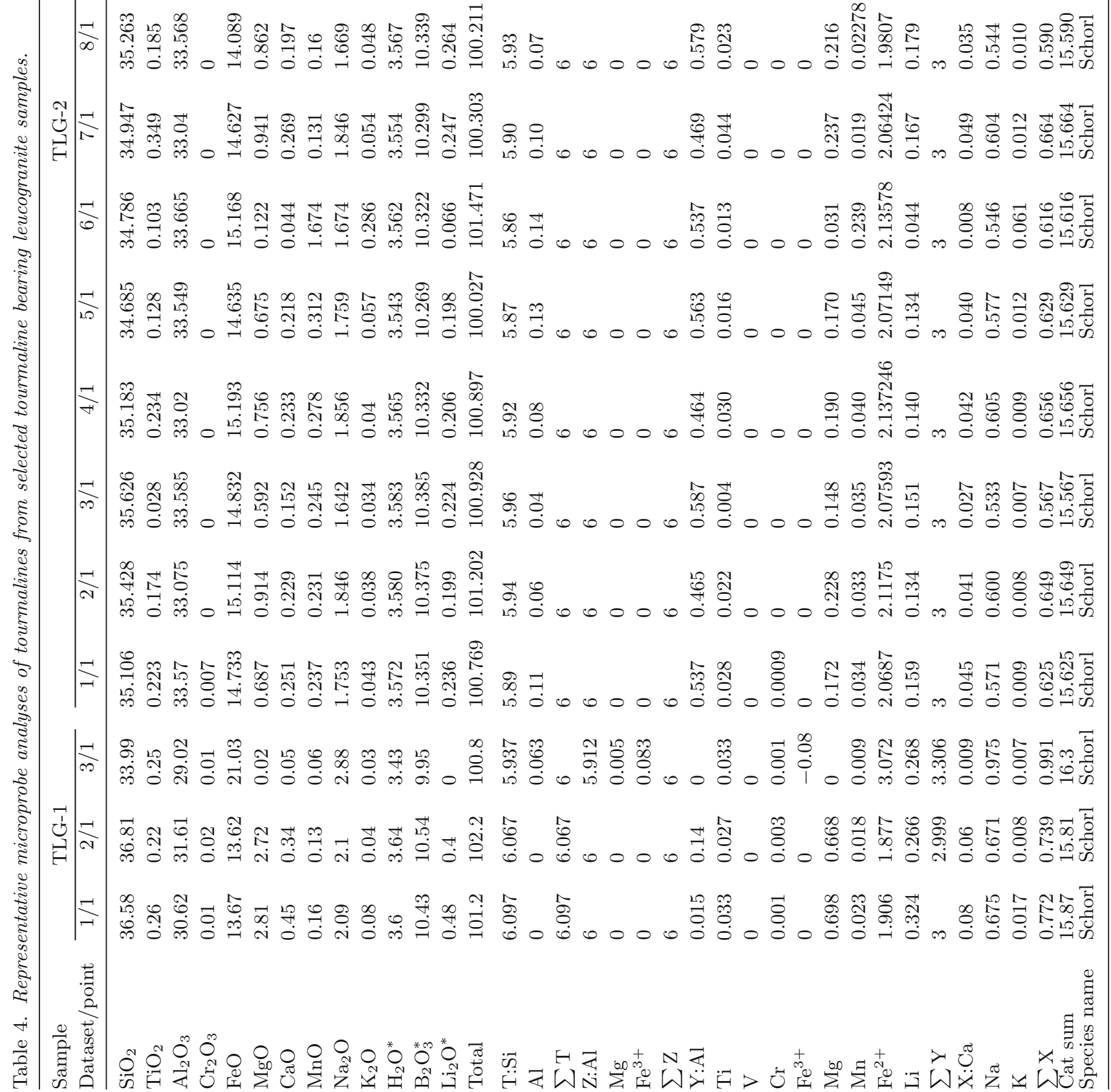




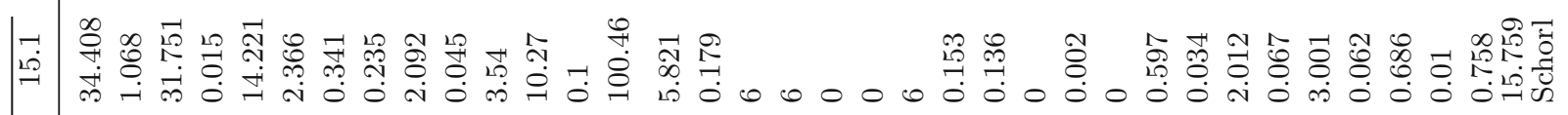

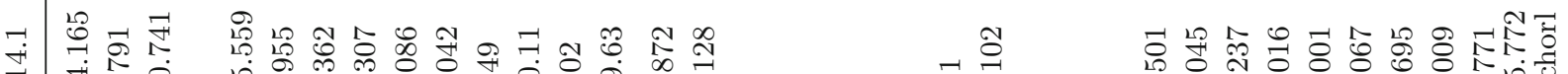

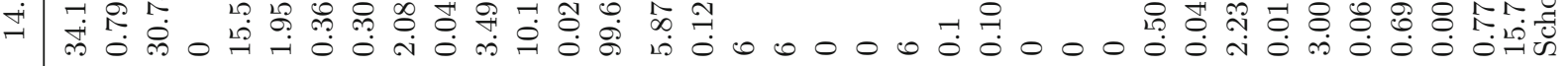

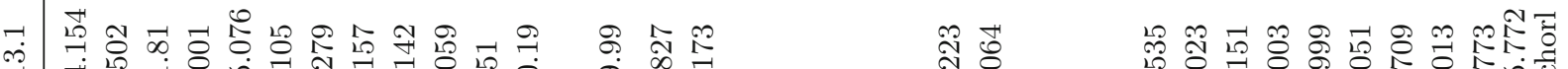

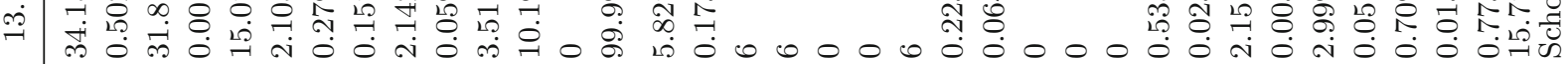

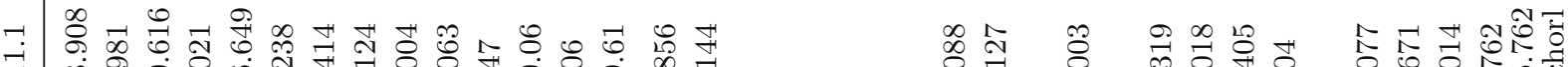

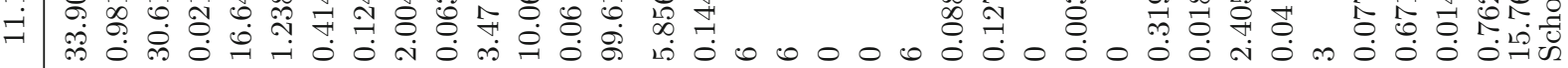

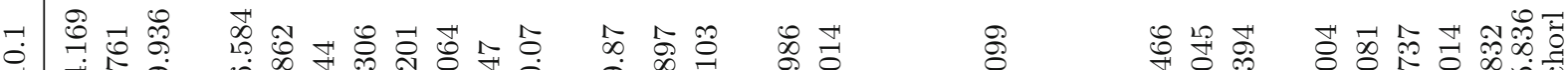
$\Rightarrow$ मे 员 में

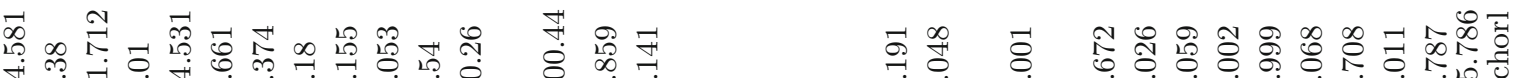
में

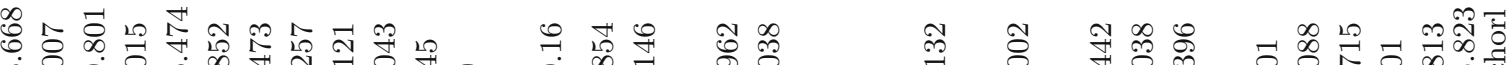
円

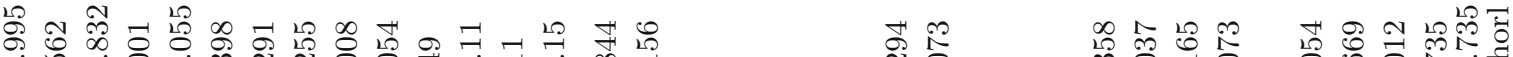
ॠ

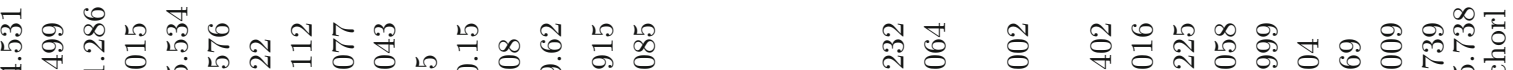
में

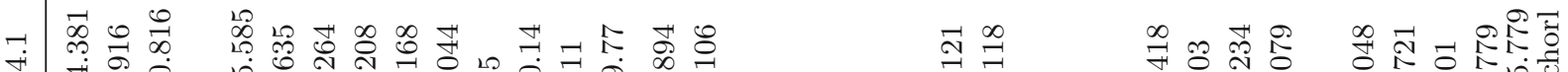

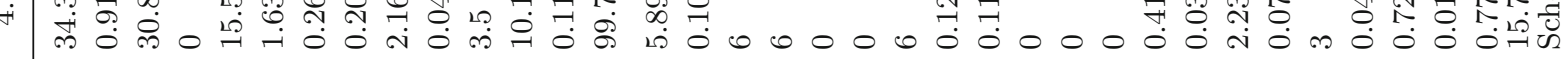

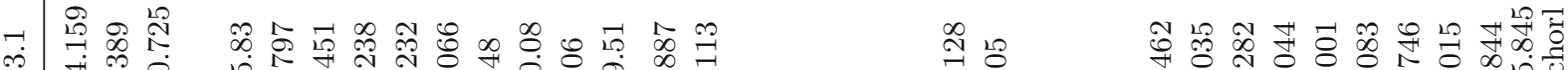

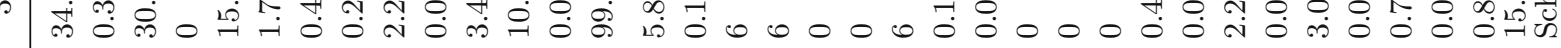

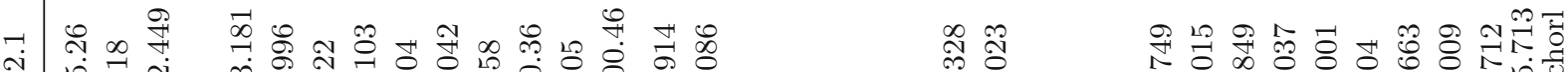

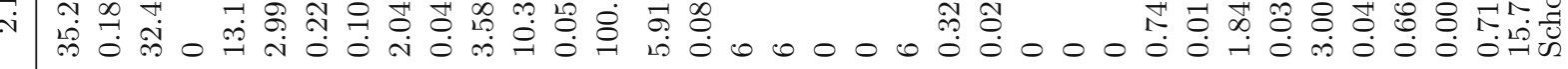
ผ

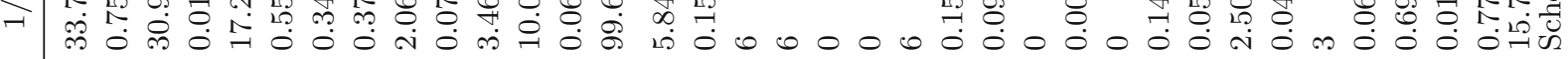

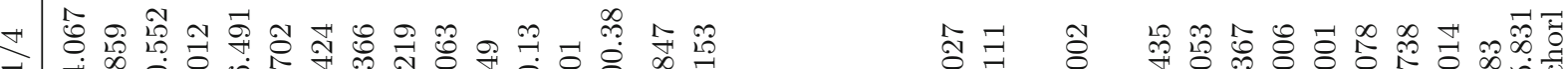

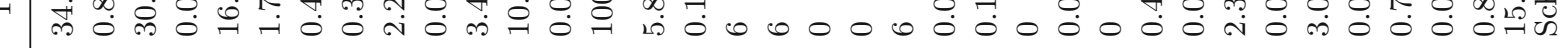

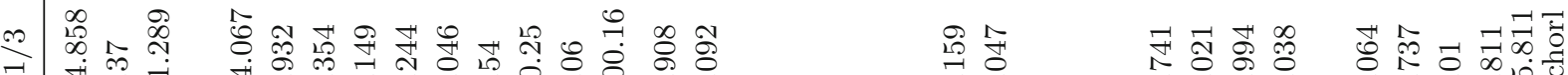
मी N में

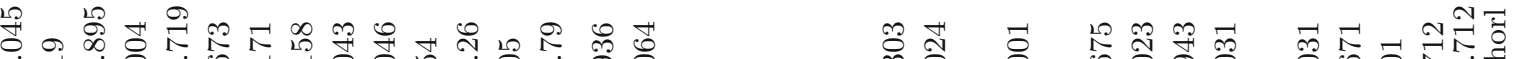

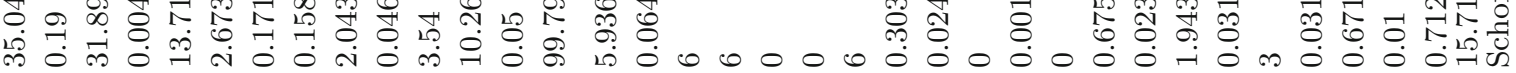

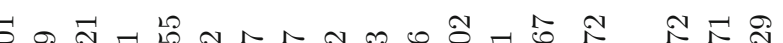

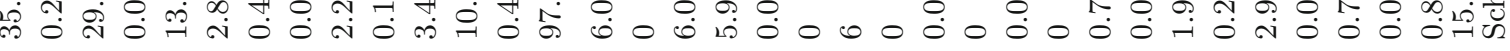

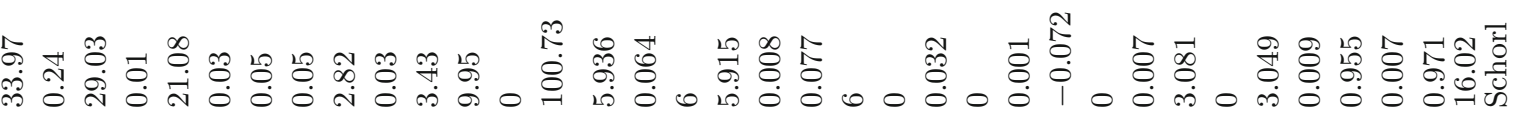
: 


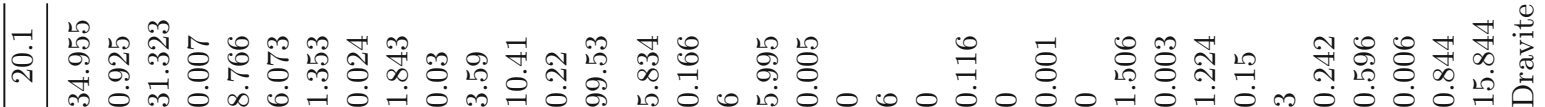

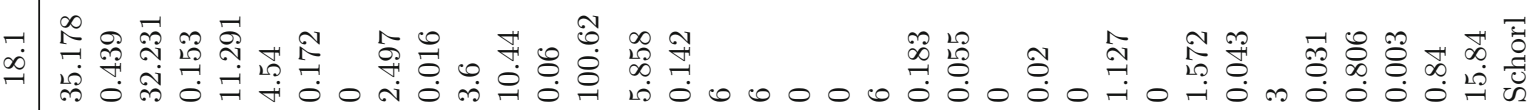

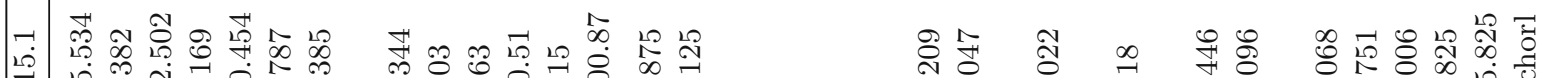

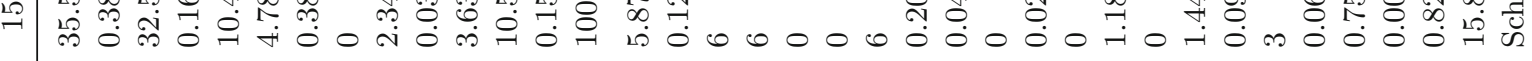

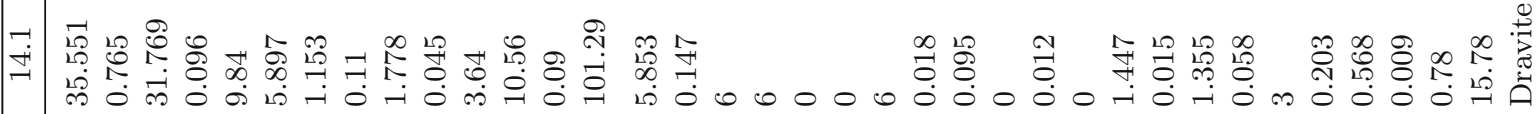

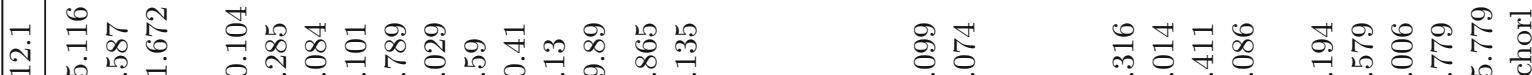

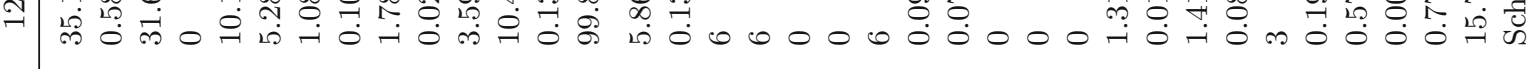

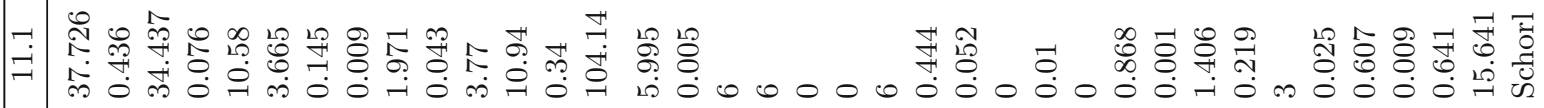

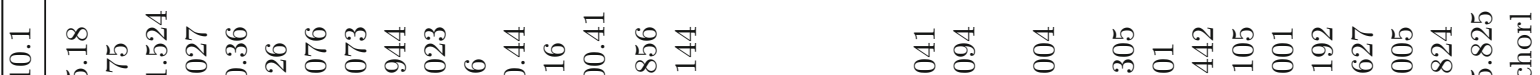

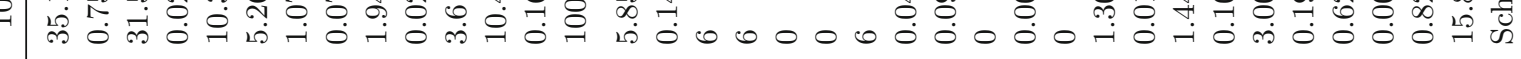
勇

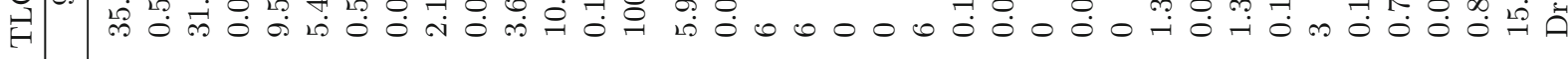

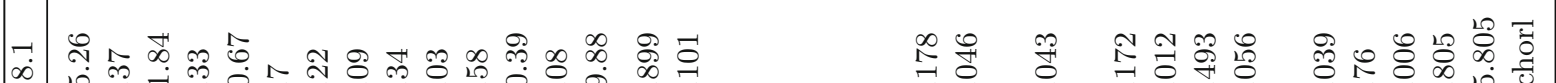

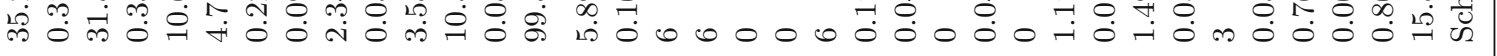

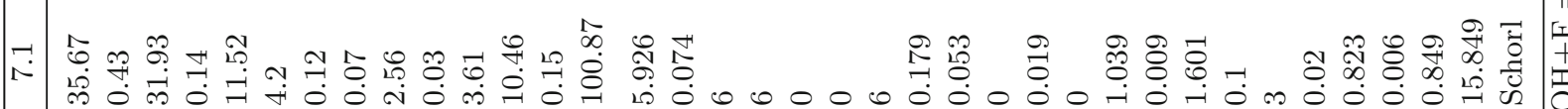

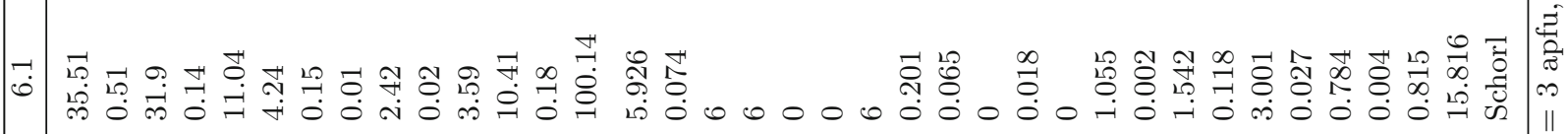

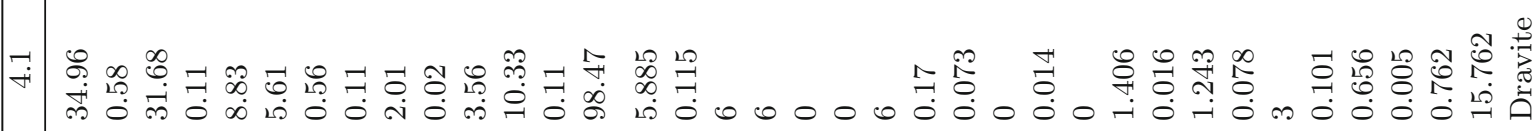

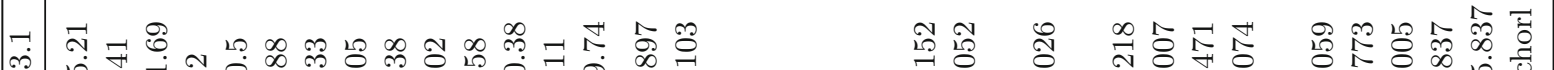
率

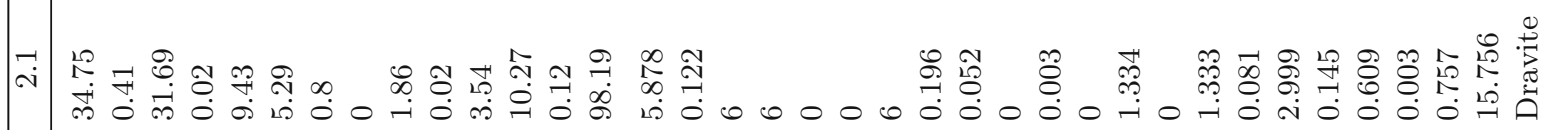

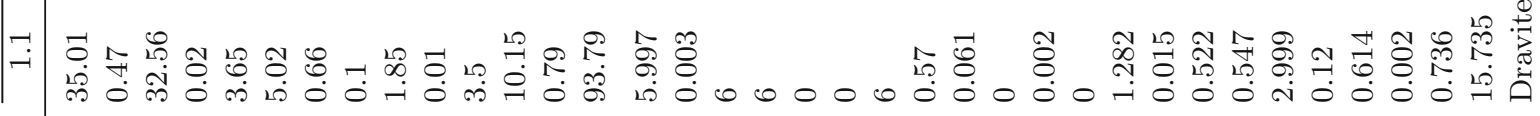


Table 5. XRF and ICP-MS data of representative tourmaline bearing leucogranite from the study area.

\begin{tabular}{|c|c|c|c|c|c|c|}
\hline Sample & TLG-1 & TLG-2 & TLG-3 & TLG-4 & TLG-5 & TLG-6 \\
\hline \multicolumn{7}{|c|}{ Major oxides (wt\%) } \\
\hline $\mathrm{SiO}_{2}$ & 72.89 & 73.64 & 73.51 & 73.53 & 74.32 & 76.09 \\
\hline $\mathrm{TiO}_{2}$ & 0.01 & 0.09 & 0.32 & 0.015 & 0.015 & 0.015 \\
\hline $\mathrm{Al}_{2} \mathrm{O}_{3}$ & 14.84 & 13.41 & 14.53 & 14.29 & 14.86 & 15.1 \\
\hline $\mathrm{MnO}$ & 0.03 & 0.02 & 0.04 & 0.02 & 0.03 & 0.02 \\
\hline $\mathrm{Fe}_{2} \mathrm{O}_{3}\left(\mathrm{FeO}_{t}\right)$ & 0.715 & 0.944 & 1.58 & 0.47 & 0.21 & 0.41 \\
\hline $\mathrm{CaO}$ & 0.53 & 0.98 & 1.3 & 0.76 & 0.36 & 0.55 \\
\hline $\mathrm{MgO}$ & 0.19 & 0.24 & 0.69 & 0.24 & 0.07 & 0.09 \\
\hline $\mathrm{Na}_{2} \mathrm{O}$ & 4.33 & 3.77 & 3.16 & 4.28 & 3.49 & 3.99 \\
\hline $\mathrm{K}_{2} \mathrm{O}$ & 5.32 & 5.52 & 5.3 & 5.01 & 7.1 & 6.15 \\
\hline $\mathrm{P}_{2} \mathrm{O}_{5}$ & 0.07 & 0.05 & 0.23 & 0.05 & 0.25 & 0.08 \\
\hline Total & 98.925 & 98.664 & 100.66 & 98.665 & 100.705 & 102.495 \\
\hline $\mathrm{A} / \mathrm{NK}$ & 1.15 & 1.10 & 1.33 & 1.15 & 1.11 & 1.14 \\
\hline $\mathrm{A} / \mathrm{CNK}$ & 2.1 & 1.9 & 2.2 & 2.1 & 2.1 & 2.1 \\
\hline $\mathrm{K} / \mathrm{N}$ & 0.8 & 1.0 & 1.1 & 0.8 & 1.3 & 1.0 \\
\hline \multicolumn{7}{|c|}{ Trace elements (ppm) } \\
\hline $\mathrm{Sc}$ & 1.75 & 1.75 & 3.6 & 1.75 & 1.75 & 1.75 \\
\hline $\mathrm{V}$ & 10 & 10 & 10 & 10 & 10 & 10 \\
\hline $\mathrm{Cr}$ & 33.8 & 42 & 82.7 & 128.7 & 36.7 & 89.5 \\
\hline $\mathrm{Co}$ & 1.2 & 2.8 & 2.7 & 0.5 & 0.5 & 0.5 \\
\hline $\mathrm{Ni}$ & 1 & 1 & 1 & 1 & 1 & 1 \\
\hline $\mathrm{Cu}$ & 21.2 & 5.6 & 31.6 & 4.7 & 0.5 & 22.6 \\
\hline $\mathrm{Zn}$ & 17 & 20.8 & 28.6 & 12 & 13 & 13.2 \\
\hline $\mathrm{Ga}$ & 24.8 & 17 & 21.4 & 12.3 & 27.4 & 19.6 \\
\hline $\mathrm{Rb}$ & 425.3 & 260.1 & 453.9 & 282.6 & 943 & 552.5 \\
\hline $\mathrm{Sr}$ & 28.6 & 82 & 97.2 & 23.6 & 35 & 17.8 \\
\hline $\mathrm{Y}$ & 2.5 & 46.3 & 10.5 & 56.9 & 2.5 & 2.5 \\
\hline $\mathrm{Zr}$ & 21.2 & 106.4 & 319.5 & 34.6 & 2.5 & 2.5 \\
\hline $\mathrm{Nb}$ & 6.8 & 7.8 & 25.5 & 6.9 & 196.2 & 2.5 \\
\hline $\mathrm{Ba}$ & 51.6 & 152.4 & 346.2 & 61 & 25 & 25 \\
\hline $\mathrm{Pb}$ & 18 & 34 & 21.9 & 29.4 & 9.6 & 21.7 \\
\hline Hf & 3.319 & 4.739 & 20.611 & 3.793 & 2.161 & 4.745 \\
\hline $\mathrm{Ta}$ & 2.895 & 0.865 & 4.676 & 1.181 & 2.535 & 122.734 \\
\hline $\mathrm{U}$ & 3.371 & 12.001 & 34.016 & 4.275 & 3.626 & 11.436 \\
\hline $\mathrm{Th}$ & 16 & 24 & 11 & 12 & 32 & 30 \\
\hline \multicolumn{7}{|l|}{ REEs (ppm) } \\
\hline $\mathrm{La}$ & 18.006 & 25.484 & 181.634 & 26.012 & 5.938 & 28.732 \\
\hline $\mathrm{Ce}$ & 33.829 & 51.033 & 309.234 & 52.703 & 12.339 & 56.455 \\
\hline $\operatorname{Pr}$ & 4.009 & 6.389 & 36.549 & 6.409 & 1.397 & 6.872 \\
\hline $\mathrm{Nd}$ & 15.494 & 22.378 & 121.914 & 22.324 & 5.134 & 25.201 \\
\hline $\mathrm{Sm}$ & 2.629 & 4.734 & 19.216 & 6.874 & 1.513 & 4.679 \\
\hline $\mathrm{Eu}$ & 0.246 & 0.372 & 1.538 & 0.442 & 0.17 & 1.066 \\
\hline $\mathrm{Tb}$ & 0.566 & 0.919 & 1.79 & 1.7 & 0.406 & 0.681 \\
\hline $\mathrm{Gd}$ & 2.451 & 5.109 & 13.501 & 8.179 & 1.82 & 4.31 \\
\hline Dy & 3.34 & 6.262 & 8.028 & 11.108 & 2.663 & 3.674 \\
\hline Ho & 0.55 & 1.182 & 1.236 & 1.921 & 0.418 & 0.56 \\
\hline Er & 1.694 & 3.899 & 3.195 & 5.505 & 1.179 & 1.411 \\
\hline $\mathrm{Tm}$ & 0.37 & 0.848 & 0.47 & 0.933 & 0.21 & 0.22 \\
\hline $\mathrm{Yb}$ & 1.89 & 4.041 & 2.914 & 5.974 & 1.437 & 1.374 \\
\hline $\mathrm{Lu}$ & 0.308 & 0.594 & 0.462 & 0.87 & 0.208 & 0.2 \\
\hline LREE & 74.0 & 110.0 & 668.5 & 114.3 & 26.3 & 121.9 \\
\hline HREE & 14.0 & 28.0 & 52.4 & 43.5 & 10.0 & 18.2 \\
\hline LREE/HREE & 5.3 & 3.9 & 13 & 3 & 2.6 & 6.7 \\
\hline $\mathrm{Ce}_{\mathrm{N}} / \mathrm{Yb}_{\mathrm{N}}$ & 4.54 & 3.2 & 26.9 & 2.24 & 2.17 & 10.46 \\
\hline $\mathrm{Eu} / \mathrm{Eu}^{*}$ & 0.30 & 0.23 & 0.29 & 0.18 & 0.32 & 0.73 \\
\hline $\mathrm{Sr} / \mathrm{Sr}^{*}$ & 0.12 & 0.23 & 0.05 & 0.07 & 0.44 & 0.05 \\
\hline
\end{tabular}

$\left(\mathrm{Eu} / \mathrm{Eu}^{*}=\mathrm{Eu}_{\mathrm{N}} / \operatorname{sqrt}\left(\mathrm{Sm}_{\mathrm{N}}^{*} \mathrm{Gd}_{\mathrm{N}}\right) ; \mathrm{Sr} / \mathrm{Sr}^{*}=\mathrm{Sr}_{\mathrm{N}} / \operatorname{sqrt}\left(\operatorname{Pr}_{\mathrm{N}} * \mathrm{Nd}_{\mathrm{N}}\right) ; \mathrm{Ce}_{\mathrm{N}} / \mathrm{Yb}_{\mathrm{N}}=\right.$ data are normalised after Nakamura $\left.(1974)\right) ;$ $\mathrm{A} / \mathrm{NK}=\mathrm{Al}_{2} \mathrm{O}_{3} / \mathrm{Na}_{2} \mathrm{O}+\mathrm{K}_{2} \mathrm{O}$ and $\mathrm{A} / \mathrm{CNK}=\mathrm{Al}_{2} \mathrm{O}_{3} / \mathrm{CaO}+\mathrm{Na}_{2} \mathrm{O}+\mathrm{K}_{2} \mathrm{O}$ in molecular proportion; $\mathrm{K} / \mathrm{N}=\mathrm{K}_{2} \mathrm{O} / \mathrm{Na}_{2} \mathrm{O}$ ratio. 

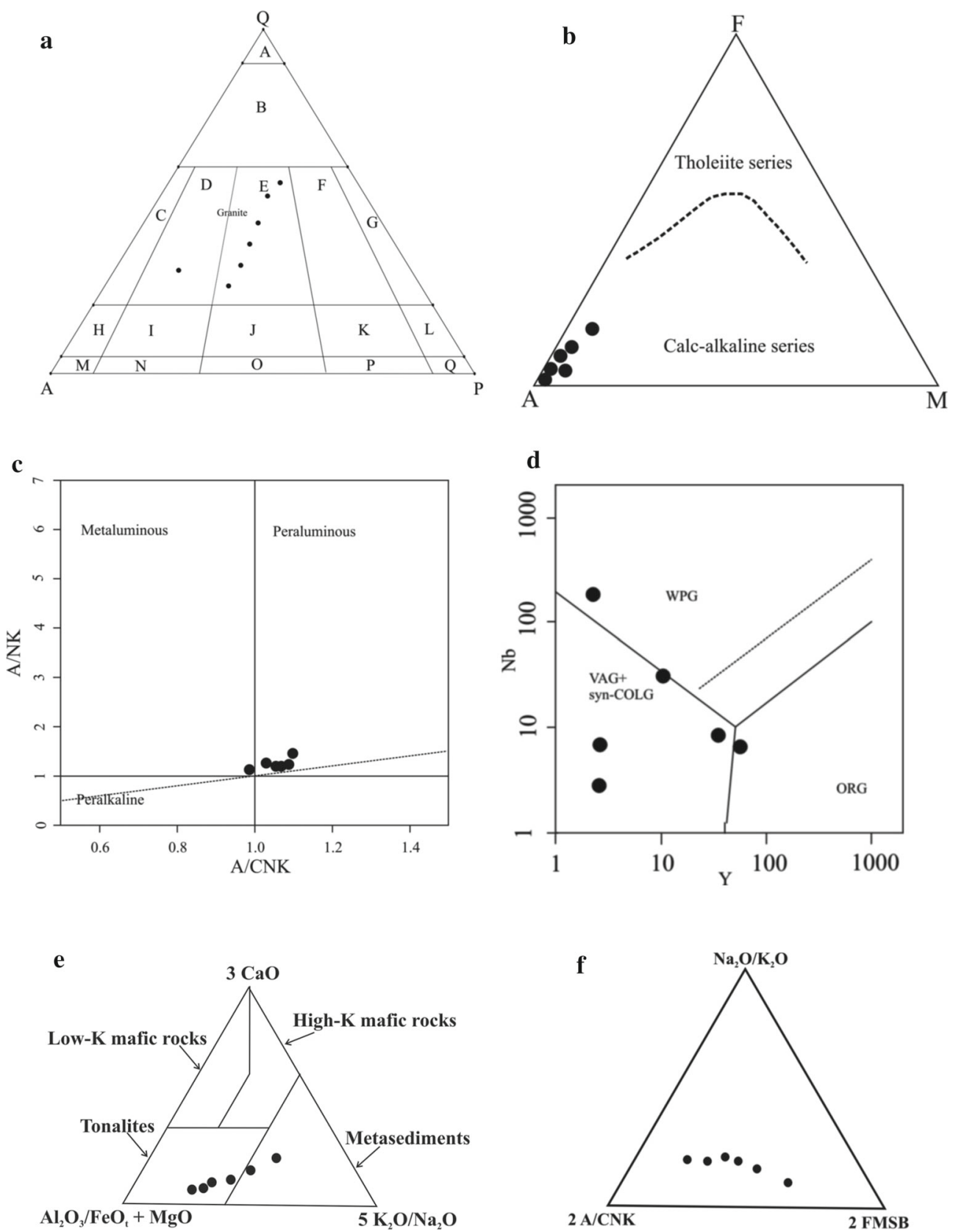

Figure 6. (a) Q-A-P diagram shows the position of leucogranites (black solid circles) in the study area (fields after Streckeisen 1976; A: quartzolite, B: quartz rich granitoids, C: alkali feldspar granite, D: syenogranite, E: monzogranite, F: granodiorite, G: tonalite, H: quartz alkali feldspar syenite, I: quartz syenite, J: quartz monzonite, K: quartz monzodiorite/quartz monzogabbro, L: quartz diorite/quartz gabbro/quartz anorthosite, M: alkali feldspar syenite, N: syenite, O: monzonite, P: monzodiorite/monzogabbro). (b) AFM diagram showing calc-alkaline affinity for tourmaline bearing leucogranite (after Irvine and Baragar 1971). (c) A/NK vs. A/CNK plot showing the peraluminous-metaluminous character of the tourmaline bearing leucogranite (after Shand and Spurr 1943; $\mathrm{A}=\mathrm{Al}_{2} \mathrm{O}_{3}, \mathrm{~N}=\mathrm{Na} 2 \mathrm{O}, \mathrm{K}=\mathrm{K} 2 \mathrm{O}, \mathrm{C}=\mathrm{CaO}$ are in molar proportion). (d) $\mathrm{Y} / \mathrm{Nb}$ plot of tourmaline bearing leucogranite of the study area (after Pearce et al. 1984). (e) $\mathrm{Al}_{2} \mathrm{O}_{3} /\left(\mathrm{FeO}_{\mathrm{t}}+\mathrm{MgO}\right)-3 \mathrm{CaO}-5\left(\mathrm{~K}_{2} \mathrm{O} / \mathrm{Na}_{2} \mathrm{O}\right)$ plot of Laurent et al. (2014) showing various fields and the possible sources of melts. (f) $2 \mathrm{~A} / \mathrm{CNK}\left(\right.$ molar $\mathrm{Al}_{2} \mathrm{O}_{3} /\left[\mathrm{CaO}+\mathrm{Na}_{2} \mathrm{O}+\mathrm{K}_{2} \mathrm{O}\right]$ ratio) $-\mathrm{Na}_{2} \mathrm{O} / \mathrm{K}_{2} \mathrm{O}$ ratio $-2(\mathrm{FeO} t+\mathrm{MgO})$ wt $\% *(\mathrm{Sr}+$ $\mathrm{Ba}$ ) wt\% (FMSB) plot of Laurent et al. (2014). End-member sources: A/CNK, Al-rich felsic rocks (TTGs, metasediments, etc.); $\mathrm{Na}_{2} \mathrm{O} / \mathrm{K}_{2} \mathrm{O}$, low-K mafic rocks; and FMSB, LILE-rich metasomatised mantle.

to 2.2, respectively. As per the tectonic plot of $\mathrm{Y} / \mathrm{Nb}$ (figure 6d), the leucogranite falls in the syncollisional and volcanic arc fields (Pearce et al. 1984). The higher concentration of $\mathrm{Cr}$ is attributed to the presence of tourmaline in the rock. Higher $\mathrm{Nb}$ compared to the low background value is due to the occurrence of columbite in the area (Mishra et al. 2016). In the $\mathrm{Al}_{2} \mathrm{O}_{3} /\left(\mathrm{FeO}_{\mathrm{t}}+\mathrm{MgO}\right)-3 \mathrm{CaO}-$ 


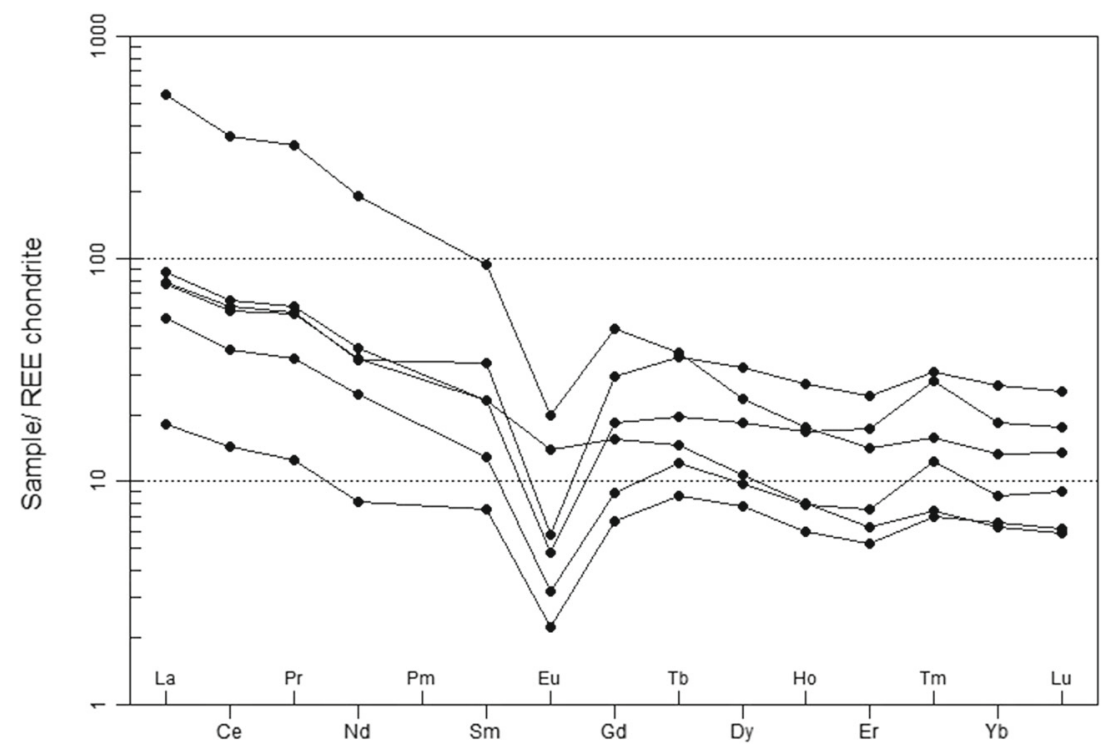

Figure 7. REE chondrite normalised spider plot of tourmaline bearing leucogranite of the study area (after Nakamura 1974).

$5\left(\mathrm{~K}_{2} \mathrm{O} / \mathrm{Na}_{2} \mathrm{O}\right)$ ternary diagram proposed by Laurent et al. (2014), samples plot in the field that represents the composition of melts derived from metasediments and tonalities (figure 6e). In the $\mathrm{Na}_{2} \mathrm{O} / \mathrm{K}_{2} \mathrm{O}-2 \mathrm{~A} / \mathrm{CNK}-2 \mathrm{FMSB}$ classification diagram, the leucogranite of the study area plot towards the A/CNK pole (figure 6f; after Laurent et al. 2014) suggests that these could be produced through partial melting of Al-rich crustal rocks including Tonalite Trondhjemite Granodiorites (TTGs) and metasediments. In the chondritenormalised REE plot of Nakamura (1974), the rock displays highly fractionated LREE indicated by a steep slope in the spider diagram (figure 7 ) with a relatively flat HREE pattern and high LREE/HREE ratio. The rock characteristically displays a strong negative EU anomaly $\left(\mathrm{Eu} / \mathrm{Eu}^{*}<\right.$ 1) caused either due to the feldspar fractionation during magma crystallisation or remaining of feldspar at the source (Graham and Ringwood 1971; Haskin 1984). The $\mathrm{Eu} / \mathrm{Eu}^{*}$ varies from 0.18 to 0.73 which indicates depleted Eu relative to the other REEs in the rock (Rollinson 1993). The negative Eu anomaly is associated with negative Sr anomaly for which plagioclase fractionation is responsible (Wilson 2007). Enriched LREE content over HREE points towards the fertile nature of the leucogranite (Mange and Morton 2007). The $\mathrm{Ce}_{\mathrm{N}}$ ranges from 14 to $74 ; \mathrm{Yb}_{\mathrm{N}}$ ranges from 2 to 28 and $[\mathrm{Ce} / \mathrm{Yb}]_{\mathrm{N}}-<27.8$. It displays high HFSE (maximum Nb up to $196 \mathrm{ppm}$, Ta up to $123 \mathrm{ppm}, \mathrm{Zr}$ up to $319 \mathrm{ppm}$ and Y up to $57 \mathrm{ppm}, \mathrm{U}$ up to $34 \mathrm{ppm})$ content.
Overall, the geochemical characters of the leucogranite are as follows. It is muscovite bearing with a $\mathrm{K} / \mathrm{Na}$ ratio up to $1.3(<2.5)$ having high $\mathrm{Rb}$ (maximum $943 \mathrm{ppm}$ ) and Th (maximum $32 \mathrm{ppm}$ ) content. It has a moderately fractionated REE pattern with $[\mathrm{Ce} / \mathrm{Yb}]_{\mathrm{N}}$ recorded up to $28\left([\mathrm{Ce} / \mathrm{Yb}]_{\mathrm{N}}<30\right)$ with a strong negative $\mathrm{Eu}$ anomaly. These are in agreement with the geochemical characters of the Archaean leucogranite as opined by Moyen et al. (2003), which could be a product of partial melting of the metasediments (Day and Weiblen 1986; Frost et al. 1998; Laurent et al. 2014).

\section{Conclusion}

The leucogranite of Bastipadu area displays strong ' $S$ ' type signatures, viz., peraluminous nature (as per the A/CNK ratio), dominance of muscovite (as per petrographic study) and high HFSE content. High $\mathrm{Rb}$ and $\mathrm{Th}$ content and $\mathrm{K} / \mathrm{Na}$ ratio, moderately fractionated REE pattern $\left([\mathrm{Ce} / \mathrm{Yb}]_{\mathrm{N}}<30\right)$ with a strong negative Eu anomaly are in broad agreement with the Archaean leucogranite formed in an arc-related setting. The geochemical signatures indicate that the melt for the leucogranite is derived from the variable contribution of two distinct sources, viz., TTGs and metasediments. The leucogranite seems to be a product of crystallisation of evolved boron-rich source (Burianek and Novak 2002). The presence of trace amount of boron in muscovite alone is sufficient to produce tourmaline leucogranite via muscovite break 
down under low degrees of partial melting (Nablek et al. 1992). The petrographic characters display the hyper solvus nature of the granite. Large-scale presence of boron in the system along with the adequate availability of $\mathrm{Fe}$ and/or $\mathrm{Mg}$ and $\mathrm{Al}$ is responsible for the formation of schorl and dravite species of tourmaline in leucogranite.

\section{Acknowledgements}

The authors are thankful to Deputy Director General, State Unit, Andhra Pradesh for the logistic support in the field, officer of Chemical Division, Southern Region for providing chemical data. The authors express sincere gratitude to the officers of the Petrology Division, GSI, SR for providing EPMA analyses. The authors are also thankful to the officers of the Petrology Division, GSI, SR for providing XRF and ICP-MS analyses.

\section{References}

Bhattacharjee S, Mishra K J, Bhimte A D and Praveen M N 2016 Structurally controlled iron oxide and copper mineralization from Kurnool District, Andhra Pradesh: Evidence for metasomatic expression of a large crustalscale alteration event; Indian J. Geosci. 70(1) 33-48.

Bhattacharjee S, Murthy S A and Reddy G P 1999 Investigation for gold and other associated elements in Chetlamallapuram area, Gadwal schist belt, Kurnool district, Andhra Pradesh; Rec. Geol. Surv. India 129(1) 69-70.

Burianek D and Novak M 2002 Tourmaline bearing leucogranite from the Trebic pluton in the Moldanubicum; Geolines 1417.

Charoy B 1982 Tourmalinisation in Cornwall, England; In: Metallization associated with acid magmatism (ed.) Evans A M, Wiley, New York, pp. 63-70.

Cobbing J 2008 The geology and mapping of granite batholiths; Springer, Berlin, Heidelberg, 96 17-65.

Day W C and Weiblen P W 1986 Origin of Late Archaean granite: Geochemical evidence from the Vermilion granitic complex of Northern Minnesota; Contrib. Mineral. Petrol. 93 283-296.

Dutrow B L, Foster C T and Henry D J 1999 Tourmaline-rich pseudomorphs in sillimanite zone metapelites: Demarcation of an infiltration front; Am. Mineral. 84(5-6) 794-805.

Dutrow B L and Henry D J 2000 Complexly zoned fibrous tourmaline, Cruzeiro mine, Minas Gerais, Brazil: A record of evolving magmatic and hydrothermal fluids; Can. Mineral. 38(1) 131-143.

Dutrow B L and Henry D J 2011 Tourmaline: A geologic DVD; Elements $\mathbf{7}(\mathbf{5})$ 301-306.

Fareeduddin, Gupta S, Golani P R, Kirmani I R and Chander S 2010 Tourmallne as metallogenic Indicator: Examples from Paleo-Proterozolc $\mathrm{Pb}-\mathrm{Zn}$ and $\mathrm{Cu}-\mathrm{Au}$ deposits of Rajasthan; J. Geol. Soc. India 76(3) 215-243.
Foit F F and Rosenberg P E 1977 Coupled substitutions in the tourmaline group; Contrib. Mineral. Petrol. 62(2) 109-127.

Frost C D, Frost B R, Chamberlain K R and Hulsebosch T P 1998 The late Archaean history of the Wyoming province as recorded by granitic magmatism in the Wind River range, Wyoming; Precamb. Res. 98 $145-173$.

Graham A L and Ringwood A E 1971 Lunar basalt genesis: The origin of the europium anomaly; Earth Planet. Sci. Lett. 13 105-115.

Grew E S and Anovitz L M 1996 Boron: Mineralogy, petrology and geochemistry; Mineralogical Society of America, Washington DC.

Grice J D and Robinson G W 1989 Feruvite, a new member of the tourmaline group, and its crystal structure; Can. Mineral. 27(2) 199-203.

Guillot S and Le Fort P 1995 Geochemical constraints on the bimodal origin of high Himalayan leucogranites; Lithos 35(3) 221-234.

Gupta S, Golani P R, Kirmani I R and Chander S 2010 Tourmaline as metallogenic indicator: Examples from paleo-proterozoic $\mathrm{Pb}-\mathrm{Zn}$ and $\mathrm{Cu}-\mathrm{Au}$ deposits of Rajasthan; J. Geol. Soc. India 76(3) $215-243$.

Gupta S, Jayananda M and Fareeduddin 2014 Tourmaline from the Archean G.R. Halli gold deposit, Chitradurga greenstone belt, Dharwar craton (India): Implications for the gold metallogeny; Geosci. Front. $\mathbf{5}$ 877-892.

Haskin L A 1984 Petrogenetic modelling-use of rare earth elements; In: Rare earth element geochemistry: Development in geochemistry (ed.) Henderson P, Elsevier Science Publisher, Amsterdam, 2 115-148.

Hawthorne F C and Henry D J 1999 Classification of the minerals of the tourmaline group; Eur. J. Mineral. 11 201-216.

Hazarika P, Mishra B and Pruseth K L 2015 Diverse tourmaline compositions from orogenic gold deposits in the Hutti-Maski greenstone belt, India: Implications for sources of ore-forming fluids; Econ. Geol. 110 337-353.

Henry D J and Dutrow B L 1992 Tourmaline in a low grade clastic metasedimentary rock: An example of the petrogenetic potential of tourmaline; Contrib. Mineral. Petrol. 112(2-3) 203-218.

Henry D J and Dutrow B L 1996 Metamorphic tourmaline and its petrologic applications; Rev. Mineral. Geochem. 33(1) 503-557.

Henry D J and Guidotti C V 1985 Tourmaline as a petrogenetic indicator mineral - An example from the staurolitegrade metapelites of NW Maine; Am. Mineral. 70(1-2) $1-15$.

Henry D J, Novák M, Hawthorne F C, Ertl A, Dutrow B L, Uher P and Pezzotta F 2011 Nomenclature of the tourmaline-supergroup minerals; Am. Mineral. 96(5-6) $895-913$.

Irvine T N J and Baragar W R A F 1971 A guide to the chemical classification of the common volcanic rocks; Can. J. Earth Sci. 8(5) 523-548.

Jowhar T N 2010 Chemistry of tourmalines from the Gangotri Granite, Garhwal higher Himalaya; Earth Sci. India 3(3) 181-194. 
Keller P, Robles E R, Perez A P and Fontan F 1999 Chemistry, paragenesis and significance of tourmaline in pegmatites of the Southern Tin Belt, central Namibia; Chem. Geol. 158(3) 203-225.

Krienitz M S, Trumbull R B, Hellmann A, Kolb J, Meyer FM and Wiedenbeck M 2008 Hydrothermal gold mineralization at the Hira Buddini Gold Mine, India: Constraints on fluid sources and evolution from boron isotopic compositions of tourmaline; Miner. Deposita $\mathbf{4 3}(\mathbf{4})$ 421-434.

Laurent O, Martin H, Moyen J F and Doucelance R 2014 The diversity and evolution of late-Archean granitoids: Evidence for the onset of 'modern-style' plate tectonics between 3.0 and $2.5 \mathrm{Ga}$; Lithos 205 208-235.

London D and Manning D A C 1995 Chemical variation and significance of tourmaline from southwest England; Econ. Geol. 90 495-519.

London D, Morgan G B and Wolf M B 1996 Boron in granitic rocks and their contact aureoles; Rev. Mineral. Geochem. 33(1) 299-330.

Mange M A and Morton A C 2007 Geochemistry of heavy minerals; In: Heavy minerals in use (eds) Mange M A and Wright D T, 58 345-391.

Manning D A C 1981 The application of experimental studies in determining the origin of topaz-quartz-tourmaline rocks and tourmaline-quartz rock; Proc. Ussher Soc. 5 121-127.

Mishra K J and Bhattacharjee S 2015 Interim report on preliminary investigation for the possible occurrence of REE and other rare metal mineralization in and around Chetlamallapuram, Kurnool district, Andhra Pradesh, (G-4 Stage); Unpublished GSI report.

Mishra K J, Bhattacharjee S, Bhimte A D, Satyanarayana K V and Mahender S 2016 Final report on the preliminary Investigation for the possible occurrence of REE and other rare metal mineralization in and around Chetlamallapuram, Kurnool district, Andhra Pradesh (G-4 stage); Unpublished GSI report.

Mishra K J and Bhattacharjee S 2017 Preliminary investigation for the possible occurrence of REE and other rare metal mineralization in and around Chetlamallapuram, Kurnool district, Andhra Pradesh; Extended abstract of progress reports of the Southern region for FS: 2014-15, Rec. Geol. Surv. India 149(5) 201-204.

Mishra K J, Bhattacharjee S, Bhimte A D, Satyanarayana K V and Mahender S 2017 Preliminary investigation for the possible occurrence of REE and other rare metal mineralization in and around Chetlamallapuram, Kurnool district, Andhra Pradesh; Unpublished GSI report.

Mohakul J P and Babu P H 2001 Granitoid hosted gold mineralization in Honnamaradi prospect, Chitradurga schist belt, Karnataka; Geol. Surv. India Spec. Publ. 58 $263-270$.

Morgan G B and Landon D 1987 Alteration of amphibolite wall rock around the Tanco rare element pegmatite, Bernic Lake, Manitoba; Am. Mineral. 772 1097-1121.

Moyen J F, Martin H, Jayananda M and Auvray B 2003 Late Archaean granites: A typology based on the Dharwar Craton (India); Precamb. Res. 127(1) $103-123$.
Nablek P I, Russ N C and Denison J R 1992 Generation and crystallisation conditions of the proterozoic Harney peak leucogranite, Black hills, South Dakota, USA, petrologic and geochemical constraints; Contrib. Mineral. Petrol. 110(2-3) 173-191.

Nakamura N 1974 Determination of REE, Ba, Fe, Mg, Na and $\mathrm{K}$ in carbonaceous and ordinary chondrites; Geochim. Cosmochim. Acta 38(5) 757-775.

Pandian M S and Dutta S K 2000 Leucogranite magmatism in Sewariya-Govindgarh areas of Rajasthan and its relevance to tungsten mineralisation; J. Geol. Soc. India 55(3) 289-296.

Pearce J A, Harris N B W and Tindle A G 1984 Trace element discrimination diagrams for the tectonic interpretation of granitic rocks; J. Petrol. 25(4) 956-983.

Pezzotta F and Laurs B M 2011 Tourmaline: The kaleidoscopic gemstone; Elements $\mathbf{7}$ (5) 333-338.

Philibert J 1963 X-ray optics and X-ray microanalysis; Academic Press, New York, 329p.

Pichamuthu C S 1962 Some observations on the structure, metamorphism, and geological evolution of peninsular India; J. Geol. Soc. India 3 106-118.

Reddy A B 1994 Investigation for gold and associated metals in parts of Gadwal schist belt, Kurnool district, Andhra Pradesh; Unpublished GSI report.

Rollinson H R 1993 Using geochemical data: Evaluation, presentation, interpretation; Prentice Hall, London, pp. 136-139.

Rosenberg P E and Foit F F 1979 The stability of transition metal dolomites in carbonate systems: A discussion; Geochim. Cosmochim. Acta 43(7) 951-955.

Sarma D S, Sawkar R H, Charan S N, Subba Rao D V and Naqvi S M 2004 Chemical composition of tourmaline in metarhyolite Near Majjur, Gadag schist belt, Karnataka; J. Geol. Soc. India 63 217-221.

Selway J 2015 Microsoft Excel spreadsheets developed by Julie Selway and Jian Xiong; (2015-12-06)[2016-05-15], http://www.open.ac.uk/earth-research/tindle/AGTWeb Pages/AGTSoft.html.

Shand Jr W and Spurr R A 1943 The molecular structure of ozone; J. Am. Chem. Soc. 65(2) 179-181.

Siva Siddaiah N and Rajamani V 1989 The geologic setting, mineralogy, geochemistry and genesis of gold deposits of the Archean Kolar schist belt, India; Econ. Geol. 84 21552172.

Slack J F 1996 Tourmaline associations with hydrothermal ore deposits; Rev. Mineral. Geochem. 33(1) 559643.

Srinivasan K N and Nagaraja Rao B K 1992 Classification of greenstones and adjoining granitoids of Gadwal schist belt of Andhra Pradesh, Unpublished GSI report.

Streckeisen A 1976 To each plutonic rock its proper name; Earth Sci. Rev. 12(1) 1-33.

Tindle A G, Breaks F W and Selway J B 2002 Tourmaline in petalite-subtype granitic pegmatites: Evidence of fractionation and contamination from the Pakeagama Lake and Separation Lake areas of northwestern Ontario, Canada; Can. Mineral. 40 753-788.

van Hinsberg V J, Henry D J and Dutrow B L 2011 Tourmaline as a petrologic forensic mineral: A unique recorder of its geologic past; Elements 7(5) 327-332. 
Watanabe J and Hasegawa K 1986 Borosilicates (datolite, schori) and aluminosilicates (andalusite, sillimanite) in the Oketo rhyolite, Hokkaido; J. Fac. Sci. Holikaido University, Series IV $\mathbf{2}$ $583-598$.
Wilson M 2007 Igneous petrogenesis; Chapman and Hall, London, pp. 13-97.

Zang J and da Fonseca-Zang W 2002 Is there really black tourmaline?; Extra Lapis English Lapis International, USA 3 30-33.

Corresponding editor: N V ChalaPATHI RAO 